Article

\title{
Origin of Blue Sapphire in Newly Discovered Spinel-Chlorite-Muscovite Rocks within Meta-Ultramafites of Ilmen Mountains, South Urals of Russia: Evidence from Mineralogy, Geochemistry, $\mathrm{Rb}-\mathrm{Sr}$ and Sm-Nd Isotopic Data
}

\author{
Elena S. Sorokina ${ }^{1,2, *}$, Mikhail A. Rassomakhin ${ }^{3}$, Sergey N. Nikandrov ${ }^{3}$, \\ Stefanos Karampelas ${ }^{4}$, Nataliya N. Kononkova ${ }^{1}$, Anatoliy G. Nikolaev ${ }^{5}$, Maria O. Anosova ${ }^{1}$, \\ Alina V. Somsikova ${ }^{1}$, Yuriy A. Kostitsyn ${ }^{1}$ and Vasiliy A. Kotlyarov ${ }^{6}$ \\ 1 Vernadsky Institute of Geochemistry and Analytical Chemistry Russian Academy of \\ Sciences (GEOKHI RAS), 119991 Moscow, Russia; nnzond@geokhi.ru (N.N.K.); \\ masha_anosova@mail.ru (M.O.A.); orlova@geokhi.ru (A.V.S.); kostitsyn@geokhi.ru (Y.A.K.) \\ 2 Institute for Geosciences, Johannes Gutenberg University Mainz, 55122 Mainz, Germany \\ 3 Ilmen State Reserve, Chelyabinsk Region, 456317 Miass, Russia; miha_rassomahin@mail.ru (M.A.R.); \\ nik@ilmeny.ac.ru (S.N.N.) \\ 4 Bahrain Institute for Pearls \& Gemstones (DANAT), WTC East Tower, P.O. Box 17236 Manama, Bahrain; \\ stefanos.karampelas@danat.bh \\ 5 Institute of Geology and Petroleum Technologies, Kazan Federal University, Department of mineralogy and \\ lithology, 420008 Kazan, Russia; anatolij-nikolaev@yandex.ru \\ 6 Institute of Mineralogy, Ural Branch Russian Academy of Sciences, Chelyabinsk Region, \\ 456317 Miass, Russia; 100126@mineralogy.ru \\ * Correspondence: elensorokina@mail.ru; Tel.: +7-(499)-137-14-84
}

Received: 19 November 2018; Accepted: 4 January 2019; Published: 11 January 2019

check for updates

\begin{abstract}
Blue sapphire of gem quality was recently discovered in spinel-chlorite-muscovite rock within meta-ultramafites near the Ilmenogorsky alkaline complex in the Ilmen Mountains of the South Urals. More than 20 minerals were found in the assemblage with the blue sapphire. These sapphire-bearing rocks are enriched in LREE and depleted in HREE (with the negative Eu anomalies) with REE distribution similar to those in miascites (nepheline syenite) of the Ilmenogorsky alkaline complex. ${ }^{87} \mathrm{Sr} /{ }^{86} \mathrm{Sr}$ ratios in the sapphire-bearing rocks varied from $0.7088 \pm 0.000004(2 \sigma)$ to $0.7106 \pm 0.000006(2 \sigma)$ : epsilon notation $\varepsilon \mathrm{Nd}$ is -7.8 . The $\mathrm{Rb}-\mathrm{Sr}$ isochrone age of $289 \pm 9 \mathrm{Ma}$ was yielded for the sapphire-bearing rocks and associated muscovite. The blue sapphires are translucent to transparent and they have substantial colorless zones. They occur in a matrix of clinochlore-muscovite as concentric aggregates within spinel-gahnite coronas. Laser Ablation-Inductively Coupled Plasma-Mass Spectrometry (LA-ICP-MS) analyses showed values with trace elements typical for "metamorphic" blue sapphires, with $\mathrm{Ga} / \mathrm{Mg}<2.7, \mathrm{Fe} / \mathrm{Mg}<74, \mathrm{Cr} / \mathrm{Ga}>1.5$ (when $\mathrm{Cr}$ is detectable), and $\mathrm{Fe} / \mathrm{Ti}<9$. Sapphires overlap "metasomatic" at "sapphires in alkali basalts" field on the $\mathrm{FeO}-\mathrm{Cr}_{2} \mathrm{O}_{3}-\mathrm{MgO}-\mathrm{V}_{2} \mathrm{O}_{3}$ versus $\mathrm{FeO}+\mathrm{TiO}_{2}+\mathrm{Ga}_{2} \mathrm{O}_{3}$ discriminant diagram. The sapphires formed together with the spinel-chlorite-muscovite rock during metasomatism at a contact of orthopyroxenites. Metasomatic fluids were enriched with Al, HSFE, and LILE and genetically linked to the miascite intrusions of Ilmenogorsky complex. The temperature required for the formation of sapphire-spinel-chlorite-muscovite rock was $700-750{ }^{\circ} \mathrm{C}$ and a pressure of $1.8-3.5 \mathrm{kbar}$.
\end{abstract}

Keywords: corundum; blue sapphire; meta-ultramafic rocks; LA-ICP-MS; Rb-Sr and Sm-Nd isotopy; Ilmenogorsky complex; Ural Mountains; metasomatism 


\section{Introduction}

Sapphire is referred to the blue color variety of corundum $\left(\mathrm{Al}_{2} \mathrm{O}_{3}\right)$ with $\mathrm{Fe}$ and $\mathrm{Ti}$ as main chromophores. Other colored sapphires are called fancy and need the color prefix (e.g., pink sapphire, colorless sapphire), apart from the red variety, which is called ruby.

Corundum, of various colors and qualities, occurs in numerous localities in the Ilmen Mountains (Figure 1a). However, gem quality sapphires are found in solely to three of them, all in situ within the primary bearing rocks (See Figure 1b, mines 298, 349, and 418) [1-7]. Occurrences are located inside of the state's Ilmen Nature Reserve, though their commercial exploitation is forbidden; samples can be collected just for research purposes in close collaboration with Nature Reserve's researchers. The most studied gem quality sapphire, of the three, is associated with alkaline syenite pegmatites (Figure 1b, mines 298 and 349), first reported by Barbot de Marni (1828) [1]. These sapphires are genetically linked with the intrusions of miascites (a leucocratic variety of nepheline syenite discovered close to Miass in the Ilmen Mountains and named after the place of discovery).

Gem-quality sapphire mineralization also occurs within the Kyshtymsky stratum of the Ilmenogorsky complex [4]. This stratum is included in the Saitovsky series [5], one of the structural units of the Vishnevogorsky-Ilmenogorsky polymetamorphic zone. This zone is a fragment of regional post-collision shear, in which the Ilmenogorsky complex is the southern unit (see more on Regional geology of Ilmenogorsky complex in [6]) (Figure 1a,b). The series is composed of meta-terrigenous quartzite-schist strata, which include garnet-feldspar-biotite, quartz-mica, and garnet-feldspar-amphibole schists; quartzites and quartzite-gneisses; and, units with mafic-ultramafic affinities. Lenses and lenticular bodies within this association are made up of olivine-enstatite, enstatite, talc-anthophyllite, talc-carbonate, tremolite-anthophyllite rocks, and various amphibolites [7]. SHRIMP U-Pb zircon dating from these rocks reflects the complex evolution of the series: 1.3 Ga (relict cores of terrigenous zircon); from about 460 to $420 \mathrm{Ma}$ (stage of metamorphic evolution), $\sim 320 \mathrm{Ma}$, and $\sim 280 \mathrm{Ma}$ (stages of collisional deformation), for more information see [5]. The dimensions of the mafic-ultramafic units, which host the sapphires, the thickness of the schists and quartzites, and their structural relationships vary widely (Figure 1c).

Gem quality sapphires were found as aggregates within chlorite-phlogopite; hosted by meta-ultramafic rocks. They were discovered at a depth of approximately $300 \mathrm{~m}$ in a drill core situated at the southern part of the Ilmen State Reserve [2]. In 2003, one of the authors (Sergey N. Nikandrov) found gem-quality sapphire in the similar micaceous (commonly muscovite) association, located between the lakes Bolshoy Tatkul and Bolshoe Miassovo (mine 418, see Figure 1b). Pink sapphires and rubies were previously found in mafic-ultramafic rocks, but this is the first occurrence of sapphires within such a spinel-chlorite-muscovite metasomatic rock.

Sapphires of gem quality are rare and they are principally found in secondary placer deposits; these are found seldom in situ and only in a few types of primary host rocks [3]. Research on gem quality sapphires found in situ in primary rocks, e.g., as those recently discovered in spinel-chlorite-muscovite rock within meta-ultramafites near the Ilmenogorsky alkaline complex in the Ilmen Mountains of the South Urals, may provide clues to the unknown petrogenesis of those from secondary placer occurrences. The present article is the first complete characterization of these sapphires, focusing on their genesis. For this, local geology and petrography were studied as well as the mineralogy, chemistry, and isotopy of corundum-spinel-chlorite-mica rocks. The results are also compared to those that were acquired on other gem-quality sapphires found in the Ilmen Mountains (syenite pegmatites) and checked their possible linkage as well as with those from other deposits for better understanding the gem corundum genesis. 

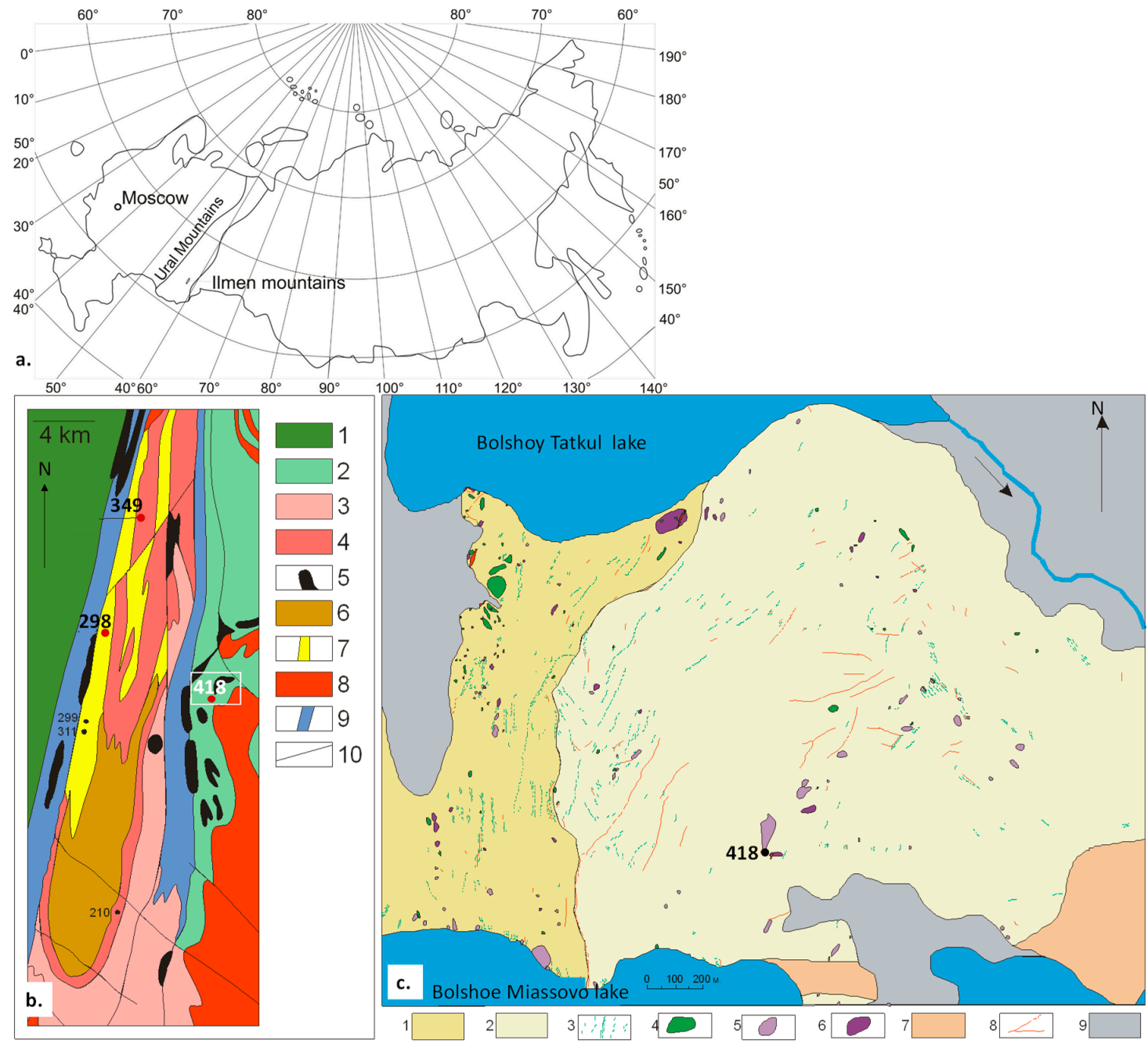

Figure 1. Location and geology of Ilmen sapphire deposits in meta-ultramafic host rocks: (a) General map of Russia showing location of Ilmen Mountains within Urals; (b) Regional geologic map of Ilmenogorsky complex after [4] with location of corundum mines within syenite pegmatites (mines 298 and 349) and within meta-ultramafic host rocks (mine 418): 1—sedimentary-volcanogenic metamorphosed rocks of the East Urals mega-zone (Upper Devonian-Lower Carboniferous), 2-volcanogenic-sedimentary metamorphosed strata of the Saitovsky series, 3-metamorphic rocks of the Ilmensky series, 4-metamorphic rocks of the Selyankinsky series, 5-meta-ultramafic rocks, 6-syenites and nepheline syenites, 7-fenites, 8-granitoids, 9-zones of blastomylonites, 10-faults, shear zones and other tectonic contacts. White box with 418 mine is shown in details in Figure 1b; (c) Regional geologic map after [8] with 418 mine of sapphire-spinel-chlorite-muscovite metasomatites within meta-ultramafic host rocks at $55.178434^{\circ} \mathrm{N}, 60.292494^{\circ} \mathrm{E}$ : 1 -Lower-Kyshtymsky stratum, generally gneiss; 2-Upper-Kyshtymsky stratum, mostly quartzite; 3-traced horizons of various rocks (biotite and amphibole gneisses, diopside-scapolitic and kyanite schists, quartzites); 4-clastoliths and bodies of amphibolites; 5-tremolite-anthophyllite meta-ultramafites; 6-enstatite ( \pm olivine) -antophyllite meta-ultramafites; 7-granite aplite; 8-granite pegmatites and granite dikes; 9—wetlands.

\section{Materials and Methods}

\subsection{Sapphires}

Five transparent to translucent colorless to blue corundum of gem quality and their solid inclusions from mine 418 were analyzed by the electron microprobe analyses (EMPA) at GEOKHI RAS using Cameca SX100 (CAMECA, Gennevilliers, France) and wavelength-dispersive (WDS) detection 
mode with $15 \mathrm{kV}$ acceleration voltage, $30 \mathrm{nA}$ beam current, and $3 \mu \mathrm{m}$ beam size. Four studied sapphire samples present pronounced colorless and blue zones and one sample was completely colorless (Figure 2b,c and Table S1). A set of natural and synthetic reference materials was used for calibration and instrument-stability monitoring. An overlap correction was applied for $\mathrm{V}>\mathrm{Ti}, \mathrm{Cr}>\mathrm{V}, \mathrm{Sc}>\mathrm{Ta}$, and $\mathrm{Nd}>\mathrm{Ce}$. The detection limits for the measured elements varied for different analytical sessions and were less than $0.01 \mathrm{wt}$. \%. Raman spectra were acquired to identify the inclusions inside the sapphires at the Gemological Institute of America laboratory (Carlsbad, CA, USA) using a Renishaw inVia Raman spectrometer combined with optical microscope. The system was coupled with $\mathrm{Ar}^{+}$laser emitting at $514 \mathrm{~nm}$ with a power of $10 \mathrm{~mW}$ on the sample. All of the measurements were from 200 to $2000 \mathrm{~cm}^{-1}$, with a $60 \mathrm{~s}$ acquisition time, three cycles, at a resolution of about $1.5 \mathrm{~cm}^{-1}$, and under $50 \times$ magnification at a room temperature. Rayleigh scattering was blocked using a holographic notch filter. Backscattered light was dispersed using a grating with 1800 grooves $/ \mathrm{mm}$. The spectrometer was calibrated at $520.7 \mathrm{~cm}^{-1}$ using $\mathrm{Si}$ as a reference.

Laser Ablation-Inductively Coupled Plasma-Mass Spectrometry (LA-ICP-MS) was performed on all five corundum samples that were previously analyzed by wavelength-dispersive electron microprobe analyses (WDS EMPA). Twenty-seven spots were measured on both blue and colorless zones (three spots on blue-colored zones of each four sapphire samples, one sapphire sample is completely colorless). Analysis took place in GEOKHI RAS using a New Wave Research UP-213 Nd:YAG laser (New Wave Research, Inc., Fremont, CA, USA) combined with Element-XR (Thermo Finnigan, Waltham, MA, USA) ICP-MS. Trace-element compositions were determined by monitoring ${ }^{6} \mathrm{Li},{ }^{9} \mathrm{Be},{ }^{24} \mathrm{Mg},{ }^{27} \mathrm{Al},{ }^{44} \mathrm{Ca},{ }^{47} \mathrm{Ti},{ }^{51} \mathrm{~V},{ }^{53} \mathrm{Cr},{ }^{55} \mathrm{Mn},{ }^{57} \mathrm{Fe},{ }^{59} \mathrm{Co},{ }^{60} \mathrm{Ni},{ }^{66} \mathrm{Zn},{ }^{71} \mathrm{Ga},{ }^{88} \mathrm{Sr},{ }^{89} \mathrm{Y},{ }^{91} \mathrm{Zr},{ }^{93} \mathrm{Nb},{ }^{181} \mathrm{Ta}$, ${ }^{208} \mathrm{~Pb}$, and ablating a material with a spot size of $55 \mu \mathrm{m}$ at a repetition rate of $4 \mathrm{~Hz}$ and an energy density of about $21.17 \mathrm{~J} / \mathrm{cm}^{2}$. Warm up/background time was $90 \mathrm{~s}$, dwell time was $100 \mathrm{~s}$, and wash out time was 120 s. NIST SRM 610 and NIST SRM 612 glasses (National Institute of Standards and Technology; U.S. Department of Commerce: Gaithersburg, MD) were used as the reference materials and ATHO as an unknown for quality control (QCM). The time-resolved signal was processed in Glitter commercial software using ${ }^{27} \mathrm{Al}$ as the internal standard applying the theoretical value of 52.93 wt. \% of $\mathrm{Al}$ in pure crystalline $\alpha-\mathrm{Al}_{2} \mathrm{O}_{3}$ for analyzing the corundum unknowns. The measured concentrations of reference material and QCM agree for all elements within 10\% and 15\%, respectively, of preferable values by [9]. This larger discrepancy between the measured and preferable values can be attributed to isobaric interferences that cannot be resolved with the instrumentation used [10].

Absorption spectra on randomly oriented blue colored zones of sample No1 and No2 were recorded at Kazan Federal University at room temperature by using SHIMADZU UV-3600 spectrometer (Shimadzu Corp, Kyoto, Japan). Spectra were acquired from 185 to $3300 \mathrm{~nm}$, with a data interval and spectral bandwidth of $1 \mathrm{~nm}$ and a scan rate of $300 \mathrm{~nm} / \mathrm{min}$.

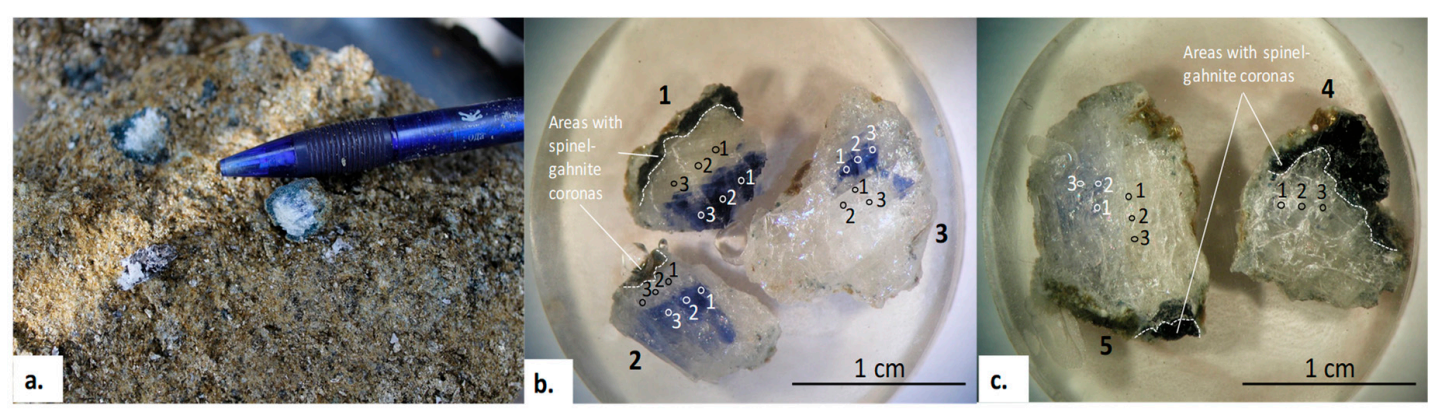

Figure 2. Photographs of corundum-spinel-chlorite-muscovite rock: (a) Corundum-spinel concentric aggregates embedded in a muscovite-chlorite matrix; (b) Corundum-blue sapphire-spinel samples No-s 1-3 with spot positions for Laser Ablation-Inductively Coupled Plasma-Mass Spectrometry (LA-ICP-MS) analyses from Table 1 mounted in the epoxy resin; (c) Corundum-blue sapphire-spinel samples No-s 4 and 5 with spots positions for LA-ICP-MS analyses from Table 1 mounted in the epoxy resin. Photographs by Elena S Sorokina. 
Table 1. The trace-elements composition of sapphire colored zones by LA-ICP-MS ${ }^{1}$.

\begin{tabular}{|c|c|c|c|c|c|c|c|c|c|c|c|c|c|c|}
\hline No & Spot & Color & ${ }^{24} \mathrm{Mg}$ & ${ }^{47} \mathrm{Ti}$ & ${ }^{51} \mathrm{~V}$ & ${ }^{53} \mathrm{Cr}$ & ${ }^{57} \mathrm{Fe}$ & ${ }^{71} \mathrm{Ga}$ & $\mathrm{Ga} / \mathrm{Mg}$ & $\mathrm{Fe} / \mathrm{Mg}$ & $\mathrm{Cr} / \mathrm{Ga}$ & $\mathrm{Fe} / \mathrm{Ti}$ & $\mathrm{Mg} \times 100$ & $\mathrm{Ti} \times 10$ \\
\hline \multirow{7}{*}{1} & 1 & $\mathrm{Cl}$ & 35.18 & Bdl & 1.05 & 56.17 & 1039.18 & 29.03 & 0.83 & 29.54 & 1.94 & - & 3518 & - \\
\hline & 2 & $\mathrm{Cl}$ & 75.09 & Bdl & Bdl & 43.46 & 1121.67 & 32.05 & 0.43 & 14.94 & 1.36 & - & 7509 & - \\
\hline & 3 & $\mathrm{Cl}$ & 46.83 & Bdl & 0.94 & 98.21 & 1072.46 & 35.79 & 0.76 & 22.9 & 2.74 & - & 4683 & - \\
\hline & 1 & $\mathrm{Bl}$ & 13.09 & 279.22 & 1.23 & 81.71 & 973.14 & 28.99 & 2.21 & 74.34 & 2.82 & 3.49 & 1309 & 2792.2 \\
\hline & 2 & $\mathrm{Bl}$ & 22.16 & 218.01 & Bdl & Bdl & 820 & 27.21 & 1.23 & 37.00 & - & 3.76 & 2216 & 2180.1 \\
\hline & 3 & $\mathrm{Bl}$ & 21.93 & 189.74 & Bdl & 70.60 & 979.65 & 31.00 & 1.41 & 44.67 & 2.28 & 5.16 & 2193 & 1897.4 \\
\hline & 1 & $\mathrm{Cl}$ & 16.03 & 49.25 & 2.46 & Bdl & 793.43 & 29.13 & 1.82 & 49.50 & - & 16.11 & 1603 & 492.5 \\
\hline \multirow{5}{*}{2} & 2 & $\mathrm{Cl}$ & 17.68 & 267.84 & 1.11 & 40.05 & 915.65 & 31.11 & 1.76 & 51.79 & 1.29 & 3.42 & 1768 & 2678.4 \\
\hline & 3 & $\mathrm{Cl}$ & 16.31 & 206.99 & 1.19 & 80.09 & 931.05 & 28.62 & 1.75 & 57.08 & 2.80 & 4.50 & 1631 & 2069.9 \\
\hline & 1 & $\mathrm{Bl}$ & 22.01 & 167.50 & 0.76 & 520.29 & 981.77 & 30.45 & 1.38 & 44.61 & - & 5.86 & 2201 & 1675 \\
\hline & 2 & $\mathrm{Bl}$ & 22.63 & 109.67 & Bdl & 63.15 & 931.31 & 28.85 & 1.28 & 41.15 & 2.19 & 8.49 & 2263 & 1096.7 \\
\hline & 3 & $\mathrm{Bl}$ & 11.69 & 129.5 & Bdl & 58.41 & 788.16 & 31.82 & 2.72 & 67.42 & 1.83 & 6.09 & 1169 & 1295 \\
\hline \multirow{7}{*}{3} & 1 & $\mathrm{Bl}$ & 15.22 & 215.82 & 1.34 & 87.16 & 1002.05 & 9.22 & 0.61 & 65.84 & 9.45 & 4.64 & 1522 & 2158.2 \\
\hline & 2 & $\mathrm{Bl}$ & 19.98 & 174.27 & Bdl & 62.49 & 1021.17 & 27.56 & 1.38 & 51.11 & 2.27 & 5.86 & 1998 & 1742.7 \\
\hline & 3 & $\mathrm{Bl}$ & 21.19 & 265.80 & 1.42 & Bdl & 853.12 & 26.88 & 1.27 & 40.27 & - & 3.21 & 2119 & 2658 \\
\hline & 1 & $\mathrm{Cl}$ & 20.34 & Bdl & 0.92 & 95.93 & 1128.79 & 33.43 & 1.64 & 55.50 & 2.87 & - & 2034 & - \\
\hline & 2 & $\mathrm{Cl}$ & 106.21 & Bdl & 1.56 & 114.49 & 767.40 & 32.59 & 0.31 & 7.23 & 3.51 & - & 10,621 & - \\
\hline & 3 & $\mathrm{Cl}$ & 36.18 & Bdl & 1.19 & Bdl & 892.02 & 32.41 & 0.90 & 24.66 & - & - & 3618 & - \\
\hline & 1 & $\mathrm{Cl}$ & 16.86 & 185.12 & 1.32 & Bdl & 686.05 & 23.21 & 1.38 & 40.69 & - & 3.71 & 1686 & 1851.2 \\
\hline \multirow[t]{2}{*}{4} & 2 & $\mathrm{Cl}$ & 15.53 & 127.12 & 1.31 & Bdl & 700.49 & 22.8 & 1.47 & 45.11 & - & 5.51 & 1553 & 1271.2 \\
\hline & 3 & $\mathrm{Cl}$ & 11.91 & 90.24 & Bdl & Bdl & 801.94 & 24.81 & 2.08 & 67.33 & - & 8.88 & 1191 & 902.4 \\
\hline \multirow{6}{*}{5} & 1 & $\mathrm{Cl}$ & 53.17 & Bdl & Bdl & Bdl & 949.86 & 26.94 & 0.51 & 17.86 & - & - & 5317 & - \\
\hline & 2 & $\mathrm{Cl}$ & 34.99 & Bdl & 1.1 & Bdl & 934.3 & 30.5 & 0.87 & 26.70 & - & - & 3499 & - \\
\hline & 3 & $\mathrm{Cl}$ & 19.22 & Bdl & Bdl & Bdl & 830.66 & 30.31 & 1.58 & 43.22 & - & - & 1922 & - \\
\hline & 1 & $\mathrm{Bl}$ & 18.58 & 247.54 & Bdl & 39.46 & 800.69 & 26.99 & 1.45 & 43.09 & 1.46 & 3.23 & 1858 & 2475.4 \\
\hline & 2 & $\mathrm{Bl}$ & 11.22 & 117.5 & 1.12 & $\mathrm{Bdl}$ & 764.53 & 27.66 & 2.47 & 68.14 & - & 6.5 & 1122 & 1175 \\
\hline & 3 & $\mathrm{Bl}$ & 12.05 & 92.4 & 1.28 & Bdl & 732.68 & 27.34 & 2.27 & 60.80 & - & 7.93 & 1205 & 924 \\
\hline
\end{tabular}

${ }^{1} \mathrm{Cl}$, BL—colorless and blue sapphire zones on a Figure $3 \mathrm{~b}, \mathrm{c} .{ }^{60} \mathrm{Ni}$ was measured but was below the detection limit.

\subsection{Host Rocks}

Ten samples extracted from different rock types at mine 418, identified macroscopically, of about 100-150 g, were selected for host rock analyses (see Figure 3a and Table S2). Whole-rock major element analyses of these samples were performed at GEOKHI RAS using Energy Dispersive X-ray Fluorescence spectrometer (EDXRF) AXIOS Advanced (PANalytical B.V., Almelo, The Netherlands). The equipment provides the determination the quantitative concentrations of elements from oxygen to uranium from about $10^{-4}$ to $100 \mathrm{wt}$. \%. The whole-rock trace element measurements were done in the Institute of Mineralogy Ural Brach Russian Academy of Sciences by using Inductively Coupled Plasma-Mass Spectrometer (ICP-MS) Agilent $7700 \times$. Agilent and GSO provided reference multi-element solutions for ICP-MS on all measured trace elements; BCR-2 basalt glass was used as the internal standard. The values of the relative standard deviations during the measurement did not exceed the values established for this analytical equipment.

For $\mathrm{Rb}-\mathrm{Sr}$ and $\mathrm{Sm}-\mathrm{Nd}$ isotope studies, powder from two samples containing gem quality sapphire (K418-12 and K418-13, Table S2) was produced. The samples 12-1, 12-2, 13-1, and 13-2 were taken from the 100-150 $\mathrm{g}$ of samples 418-12 and 418-13 used previously for EDXRF and ICP-MS. Another 2 samples (rock1 and rock2) from a bigger portion of about $1 \mathrm{~kg}$ of sample $418-13$ with sapphire, spinel, feldspar, and muscovite in minerals association, as well, as two muscovites (mica1 and mica2) extracted from appropriate samples rock1 and rock2 were chosen to constrain the $\mathrm{Rb}-\mathrm{Sr}$ age. Sample dissolution was carried out in a mixture of hydrofluoric and nitric acids (5:1) on a shaker under incandescent lamps during three days. After evaporation, $1 \mathrm{~mL}$ of concentrated $\mathrm{HCl}$ acid was added three times to a dry residue. $\mathrm{Rb}, \mathrm{Sr}$, and REE were collected using fluoroplastic chromatographic columns with DowexW $50 \times 8$ synthetic ion-exchange resin. The collection was done by stepwise elution with 2.2 acid normality (n) of $\mathrm{HCl}$ (for $\mathrm{Rb}$ and $\mathrm{Sr}$ ) and $4.0 \mathrm{n} \mathrm{HCl}$ (for the $\mathrm{Sm}+\mathrm{Nd}$ ). From the REE mixture, Sm and Nd were collected by stepwise elution with $0.15 \mathrm{n} \mathrm{HCl}, 0.3 \mathrm{n} \mathrm{HCl}$, and $0.7 \mathrm{n}$ $\mathrm{HCl}$ using polyethylene columns with synthetic ion-exchange resin Ln-spec. The isotopic studies took place on a Finnigan ${ }^{\mathrm{TM}}$ Triton multi-collector thermal ionization mass-spectrometer (TIMS) by ThermoFisher Scientific (Waltham, MA, USA) at GEOKHI RAS while using a two-tape (Re-Re) ion source for $\mathrm{Rb}, \mathrm{Sm}$, and $\mathrm{Nd}$ and a single-tape (Re) ion source for $\mathrm{Sr}$. Measurements were performed in static mode with simultaneous recordings of ion currents for different isotopes. For the elimination 
of mass-dependent interference, normalization was carried out according to the exponential law for ${ }^{86} \mathrm{Sr} /{ }^{88} \mathrm{Sr}=0.1194$ and ${ }^{148} \mathrm{Nd} /{ }^{144} \mathrm{Nd}=0.241572$. The analyses of the international standards Sr-SRM-987 and $\mathrm{Nd}$-LaJolla monitored the reproducibility and correctness of isotope measurements for $\mathrm{Sr}$ and $\mathrm{Nd}$. The average value of ${ }^{87} \mathrm{Sr} /{ }^{86} \mathrm{Sr}=0.710236 \pm 0.000009(2 \sigma)$ and ${ }^{143} \mathrm{Nd} /{ }^{144} \mathrm{Nd}=0.512095 \pm 0.000006$ $(2 \sigma)$. Concentrations of $\mathrm{Rb}, \mathrm{Sr}, \mathrm{Sm}$, and $\mathrm{Nd}$ were determined by isotopic dilution using ${ }^{85} \mathrm{Rb}-{ }^{84} \mathrm{Sr}$ and ${ }^{149} \mathrm{Sm}-{ }^{150} \mathrm{Nd}$ tracers. The data-reduction was performed using in-lab software. Isoplot4.13 for Excel [11] was used for isochrone diagram with MSWD $=4.1$.

Eight petrographic thin-sections of visually monolithic host rocks (samples 418-3, 418-4, 418-6, 418-7, 418-9. 418-10, 418-11, and 418-14), 24 randomly chosen corundum-spinel-chlorite-mica (sample 418-12) and one corundum-spinel (sample 418-13) wafers were studied for petrography (see Table S2). Ten of these wafers with different corundum morphology were used to perform the chemical composition of minerals found in association with corundum by EMPA at the Institute of Mineralogy Ural Branch Russian Academy of Sciences (Miass, Russia) using the electron microscope REMMA-202 M coupled to energy-dispersive spectrometer LZ-5. The operating conditions are 20-30 kV acceleration voltage and 4-6 nA beam current. The beam sizes varied from 1 to $2 \mu \mathrm{m}$. A set of natural and synthetic reference materials was used for calibration and instrument-stability monitoring.
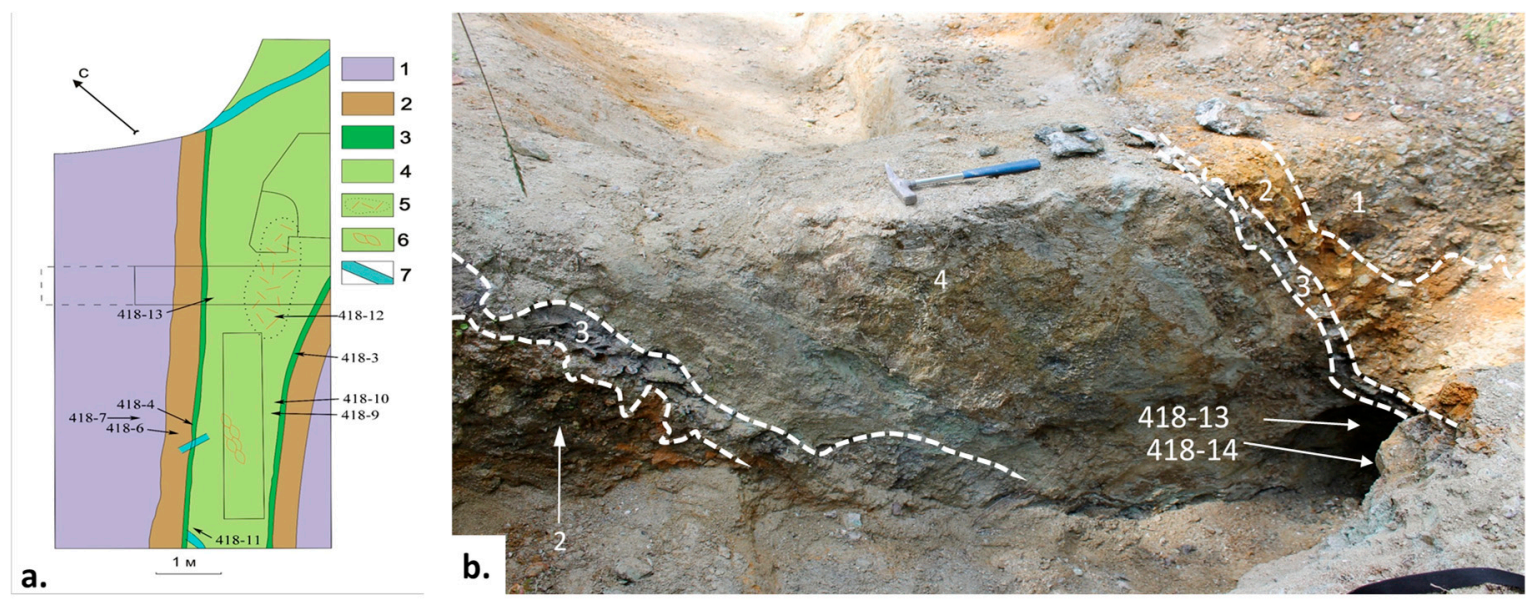

Figure 3. Local geologic maps of 418 mine showing the locations of samples for this research at $55.178434^{\circ} \mathrm{N}, 60.292494^{\circ} \mathrm{E}$ : (a) Geological scheme of 418 mine: 1 -meta-ultramafites; 2-ferruginated meta-ultramafites; 3-talc meta-ultramafites altering toward the center on a dense actinolite rock; 4-actinolite rock; 5-micaceous lenses with corundum; 6-lenses of actinolite-micaceous rock; 7-anthophyllite-asbestos veins; (b) The outcrop of 418 mine: 1-meta-ultramafic host rock of the main unit; 2-ferruginated and carbonated meta-ultramafites of the near-selvage zone; 3-talc zone in meta-ultramafic host rock; 4 - the central zone. The numbers 418-3, 418-4, 418-6, 418-7, 418-9, 418-10, 418-11, 418-12, 418-13, and 418-14 indicate the numbers of samples in Table S1.

\section{Results}

\subsection{Geology and Petrology of Sapphire-Bearing Rocks and Meta-Ultramafic Host Rocks}

Sapphire occurrence is a plate-shaped symmetrical-zonal body with traces of considerable deformation, with a dip azimuth of $330^{\circ}$; dip angle is $40^{\circ}$; and, its thickness varies from 1.0 to $1.3 \mathrm{~m}$ (Figure 3a). The mine 418 with sapphire-spinel-chlorite-muscovite rock was opened from the surface by a trench measuring about $4 \times 9 \mathrm{~m}$ (Figure $3 \mathrm{~b}$ ). The block of meta-ultramafites hosting corundum-spinel-chlorite-muscovite rock occupied the first tens of meters and up to about $35 \mathrm{~m}$ along the drainage ditch (Figure 3a). The meta-ultramafic host rocks consist of purely mono-mineral coarse-grained enstatite up to $4-5 \mathrm{~cm}$ in length with minor olivine and clinopyroxene; in some areas, they are replaced by talc and chrysotile-asbestos. Besides, there is a completely replaced pyrite by 
goethite in the rock. In the surface subsoil layer, there are chalcedony-quartz concretions up to $10 \mathrm{~cm}$ in length, while limonite and supergenic carbonate developed along the cracks of host rocks.

The following zones are distinguished by the structure of host and corundum-bearing rocks (from the selvage to the center, Figure 3b): 1. Meta-ultramafic host rock, which is macroscopically composed of orthopyroxene and clinopyroxene, and minor olivine, have clearly visible brittle deformations (sample 418-7, Table S2); 2. The ferruginated and carbonated meta-ultramafic host rock of the near-selvage zone has a common brownish-orange color; its minerals are almost completely replaced by quartz and carbonate; however, relics of olivine were still detectable (sample 418-6); 3 . Talc zoning in the meta-ultramafic host rock (sample 418-4) alternates towards the center on a dense green-colored rock (sample 418-3). The transition to green-colored rock is smooth from almost mono-mineral talc to mono-mineral amphibole. In the amphibole zone, in addition to the monoclinic amphibole (actinolite-tremolite), rhombic anthophyllite was also detected; 4. The central zone is strongly affected by both weathering and deformation processes and it consists of lenticular lenses of various compositions (mica -sample 418-11-, actinolite, actinolite-mica, micaceous pockets with corundum, spinel pockets). In this zone, actinolite-tremolite rock is replaced by shallow rot; only small fragments remain in individual lenses (samples 418-9 and 418-10). The corundum, spinel, and other minerals that accompany them (Figure 2a-c) came from this zone during mineralogical studies described below (samples 418-12, 13, and 14).

\subsection{Mineralogy of Sapphire-Hosted Micaceous Lenses}

Two sapphire associations were identified, accompanied by spinel. In one, sapphire forms transparent to translucent crystals within the spinel corona. In the other, one lens is an assembly of small (sized about $1 \mathrm{~cm}$ ) transparent to translucent corundum crystals with almost black spinel, not forming a corona around corundum crystals.

More than 20 major, minor, and accessory minerals are associated with sapphires. Some minerals are common (spinel, clinochlore etc.) and others represent rare or single findings (Ni-bearing sulfide mineralization and baddeleyite) (Table S3. Their texture relationships in regard of sapphire are shown in Table S4. Most minerals were identified under the optic microscope and by Raman Spectroscopy; chemical compositions of minerals were analyzed by EMPA and are presented in Tables S5-S12.

\subsubsection{Major Minerals}

Minerals of spinel- $\mathrm{MgAl}_{2} \mathrm{O}_{4}$-gahnite $\mathrm{ZnAl}_{2} \mathrm{O}_{4}$ series were common detected in $3 \mathrm{~mm}$ thick dark green to black-colored corona around sapphire crystals, as well as in inclusions (Figure 4a). The dark-green to black color is likely due to Fe; Co traces (up to $0.28 \mathrm{wt}$. \%) may also contribute to the coloration. Induction surfaces (i.e., surfaces of synchronous growth) that were detected between spinel and sapphire suggest their synchronous growth. However, spinel most likely started crystallizing at a slightly later stage and when sapphire was already growing in the system. Gahnite appears in spinel areas with higher $\mathrm{ZnO}$ contents (up to $22 \mathrm{wt}$. \%). In zonal grains, $\mathrm{ZnO}$ values varied from 2.46 to $7.47 \mathrm{wt}$. \% (Table S5). Muscovite $\mathrm{KAl}_{2}\left(\mathrm{AlSi}_{3} \mathrm{O}_{10}\right)(\mathrm{OH})_{2}$ formed micaceous lenses with embedded corundum, as well as micro-inclusions (up to $0.2 \mathrm{~mm}$ ) within chlorite group minerals (Figure $4 \mathrm{~b}$ ). Muscovite is characterized by a higher $\mathrm{MgO}$ content from 0.5 to $2.5 \mathrm{wt}$ \% in comparison to stoichiometric muscovite (Table S6). Clinochlore $\mathrm{Mg}_{5} \mathrm{Al}_{(}\left(\mathrm{AlSi}_{3} \mathrm{O}_{10}\right)(\mathrm{OH})_{8}$ and amesite $\mathrm{Mg}_{2} \mathrm{Al}\left(\mathrm{AlSiO}_{5}\right)(\mathrm{OH})_{4}$ form inclusions and rather large ingrowths (up to $5 \mathrm{~mm}$ ) around spinel, inclusions within spinel, and in fractures along the border of corundum and spinel (Figure $4 \mathrm{~b}$ ). These minerals were also found in the rims around the uraninite-brockite and monazite-(Ce) (for the chemical composition, Table S6). Anorthite $\mathrm{CaAl}_{2} \mathrm{Si}_{2} \mathrm{O}_{8}\left(\mathrm{An}_{100}\right)$ is found in the "spinel lenses" forming crystals that are sized up to $3 \mathrm{~mm}$ in the intergrowth with amphibole and chlorite group minerals (see chemical composition in Table S7). All identified major minerals are syngenetic with sapphire. 

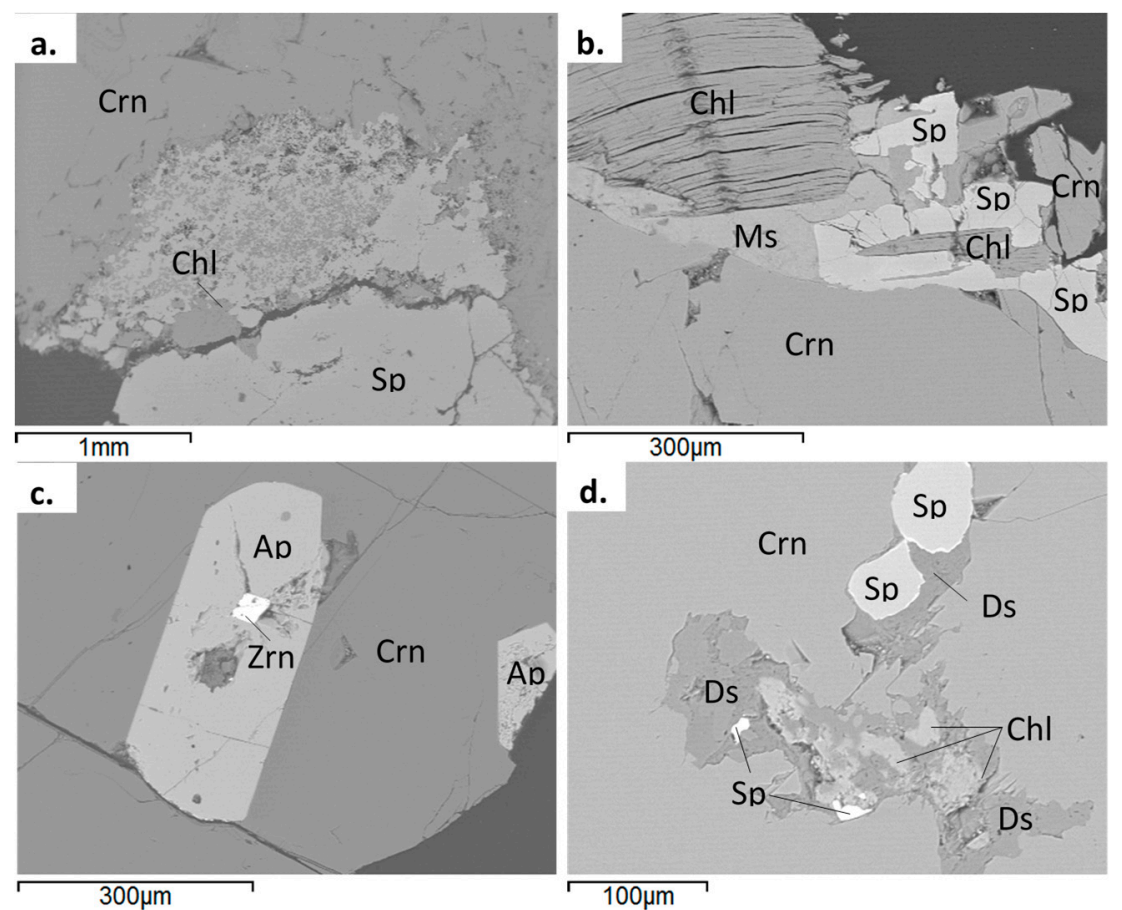

Figure 4. Backscattered (BSE) images of corundum-spinel-chlorite samples from the central zone: (a) Corundum-spinel intergrowth with inclusions of clinochlore; (b) The rim of corundum-spinel concentric aggregate with intergrowth of clinochlore and muscovite; (c) Inclusions of apatite and zircon within corundum; and, (d) Inclusions of spinel, clinochlore, and diaspore (Ds) within corundum. Mineral abbreviations are after [12]. BSE images by E.S. Sorokina.

\subsubsection{Minor Minerals}

Apatite group minerals $\mathrm{Ca}_{5}\left(\mathrm{PO}_{4}\right)_{3}(\mathrm{OH}, \mathrm{F}, \mathrm{Cl})$ were found within corundum fractures and chlorite group minerals as prismatic epigenetic inclusions up to $1 \mathrm{~mm}$ in length (Figure 4c). Its composition varies from chlorapatite to fluorapatite to hydroxylapatite (Table S8). Zircon $\mathrm{ZrSiO}_{4}$ forms small zonal epigenetic inclusions (up to $0.1 \mathrm{~mm}$ in length) within the fractures of corundum, chlorite group minerals, and spinel. Besides zircon, the amphibole group minerals and apatite (Figure 4c) also fill out these fractures. Zircons contain up to 3.16-4.73 wt. \% of $\mathrm{HfO}_{2}$ (Table S9). Protogenetic diaspore $\mathrm{AlO}(\mathrm{OH})$, along with clinochlore forms rims around inclusions of uraninite, intergrowth with clinochlore within corundum (Figure 4d), and platy aggregates in the fractures of barium feldspar. Diaspore contain up to $0.1 \mathrm{wt}$. \% of $\mathrm{SiO}_{2}$ and $0.34 \mathrm{wt}$. \% of $\mathrm{FeO}_{\text {tot. }}$ Millerite NiS forms micro-inclusions (up to $15 \mu \mathrm{m}$ ) within corundum, spinel, and chlorite group minerals; the mineral is found in association with maucherite, heazlewoodite, and galena (Figure 5a). The $\mathrm{FeO}_{\text {tot }}$ content of millerite varies from 2 to 20 wt. \% (Table S10). Maucherite $\mathrm{Ni}_{11} \mathrm{As}_{8}$ was detected in the intergrowth with heazlewoodite and millerite in crystals sized to $15 \mu \mathrm{m}$ (for chemical composition, Table S10). Microlite group minerals $(\mathrm{Na}, \mathrm{Ca})_{2} \mathrm{Ta}_{2} \mathrm{O}_{6}(\mathrm{O}, \mathrm{OH}, \mathrm{F})$ were found in small (up to $0.1 \mathrm{~mm}$ ) grains and cube-octahedral crystals within chlorite group minerals (Figure $5 b$ ). Minerals characterized by the high $\mathrm{UO}_{2}$ content (up to 11.34 wt. \%); values of $\mathrm{WO}_{3}$ and $\mathrm{Nb}_{2} \mathrm{O}_{5}$ both vary up to 3.15 wt. $\%$ and 3.57 wt. \%; $\mathrm{ThO}_{2}$ is 1.2 wt. $\%$ and $\mathrm{Y}_{2} \mathrm{O}_{3} 1.61$ wt. \%. Nickeline NiAs is found as inclusions within clinochlore and dravite; the size of mineral varied up to $20 \mu \mathrm{m}$ (Figure $5 \mathrm{c}$ and Table S9). Uraninite $\mathrm{UO}_{2}$ forms zonal micro-inclusions that are sized up to $150 \mu \mathrm{m}$ (Figure $5 \mathrm{~d}$ ). The atomic number (pfu) is up to 0.41 in the mineral. Allanite- $(\mathrm{Ce})(\mathrm{CaCe})\left(\mathrm{Al}_{2} \mathrm{Fe}^{2+}\right)\left(\mathrm{Si}_{2} \mathrm{O}_{7}\right)\left(\mathrm{SiO}_{4}\right) \mathrm{O}(\mathrm{OH})$-dissakisite-(Ce) $(\mathrm{CaCe})\left(\mathrm{Al}_{2} \mathrm{Mg}\right)\left(\mathrm{Si}_{2} \mathrm{O}_{7}\right)\left(\mathrm{SiO}_{4}\right) \mathrm{O}(\mathrm{OH})$ form zonal-sectorial and mosaic-like crystals up to $0.2 \mathrm{~mm}$ in length (Figure 5f); the oscillatory zonation is due to the different concentrations of $\mathrm{CaO}$ and REE (Table S11). Monazite-(Ce) $\mathrm{Ce}\left(\mathrm{PO}_{4}\right)$ has been found along the cracks of dissakisite-(Ce) grains, forming crystals of up to $20 \mu \mathrm{m}$ in length (Figure $5 \mathrm{f}$ ). $\mathrm{CaO}$ content ranges from 0.38 to $8.25 \mathrm{wt}$. \% in the mineral, 
$\mathrm{Ce}_{2} \mathrm{O}_{3}$ values vary from 23.11 to 37.53 wt. \%, and $\mathrm{La}_{2} \mathrm{O}_{3}$ is $10-22$ wt. \%; in some analyses, additional $\mathrm{SiO}_{2}$ and $\mathrm{ThO}_{2}$ were detected (Table S9). Ni-bearing and REE-mineralization are likely syngenetic in origin.
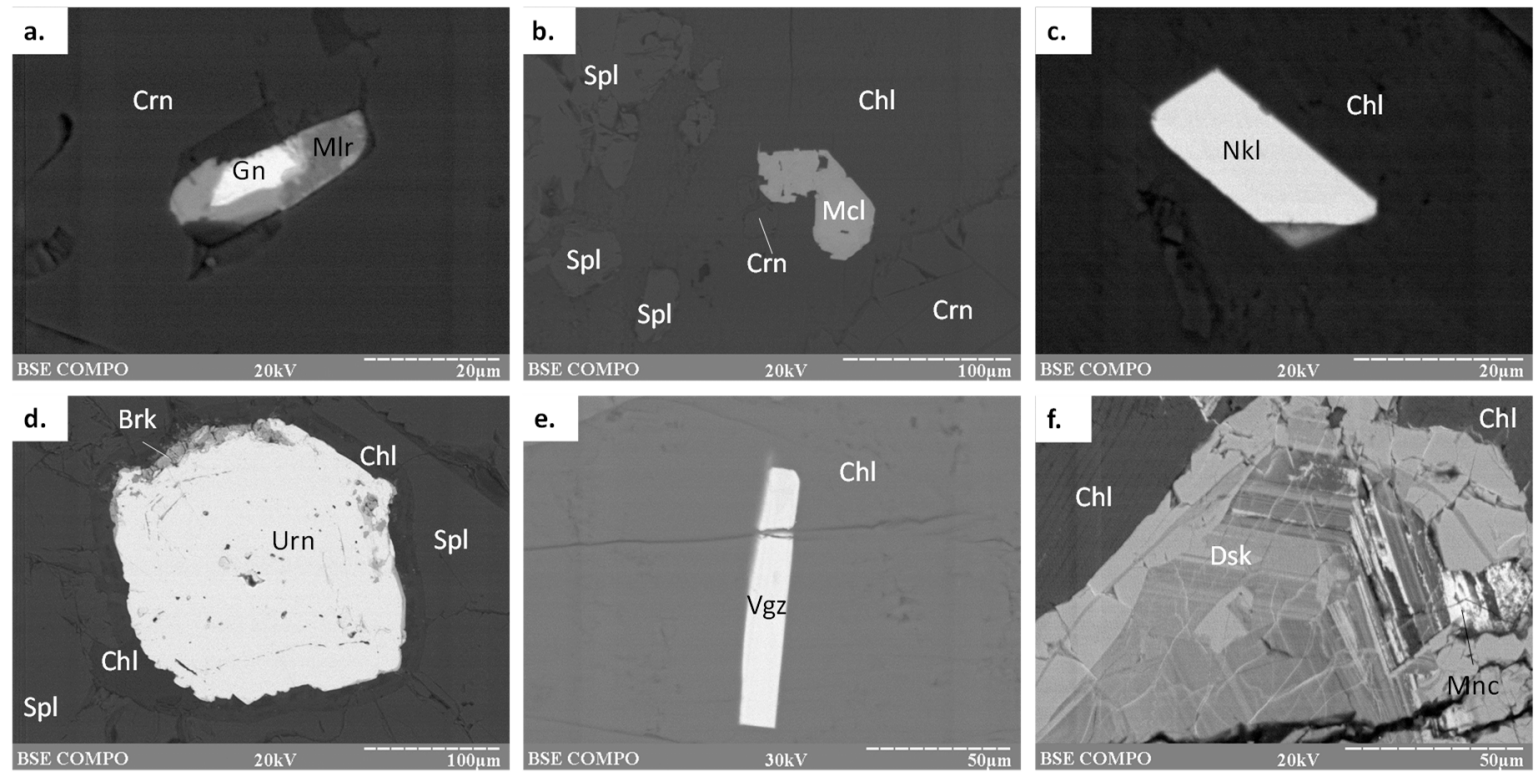

Figure 5. BSE images of corundum-spinel-chlorite samples from the central zone: (a) Millerite and galena inclusions within corundum; (b) Corundum-spinel-clinochlore intergrowth with inclusion of microlite; (c) Nickeline inclusion within clinochlore; (d) Uraninite-brokkite-clinochlore concentric aggregate within spinel; (e) Vigezzite inclusion within clinochlore; and, (f) Dissakisite-(Ce)-monazite-(Ce) aggregate within clinochlore. Mineral abbreviations are after [12]. BSE images by V.A. Kotlyarov.

\subsubsection{Accessory Minerals}

Vigezzite or fersmite $(\mathrm{Ca}, \mathrm{Ce})(\mathrm{Nb}, \mathrm{Ta}, \mathrm{Ti})_{2} \mathrm{O}_{6}$ forms likely syngenetic elongate-prismatic inclusions up to $70 \mu \mathrm{m}$ long within clinochlore (Figure $5 \mathrm{e}$ ). The content of $\mathrm{Nd}_{2} \mathrm{O}_{3}$ is about $3.5 \mathrm{wt}$. \% in the mineral; $\mathrm{La}_{2} \mathrm{O}_{3}$ values vary up to 2.16 wt. \%, $\mathrm{Pr}_{2} \mathrm{O}_{3}$ is up to 1.15 wt. \%; and, $\mathrm{FeO}_{\text {tot }}$ up to 1 wt. \%.

Heazlewoodite $\mathrm{Ni}_{3} \mathrm{~S}_{2}$ is associated with corundum, spinel, clinochlore, and millerite. The size of the mineral is less than $0.3 \mathrm{~mm}$. It contains up to $1.22 \mathrm{wt}$. \% of $\mathrm{FeO}_{\text {tot }}$ [13]. Galena $\mathrm{PbS}$ is found in intergrowth with millerite in the form of crystals sized up to $10 \mu \mathrm{m}$ (Figure $5 \mathrm{a}$ and Table S10). Gersdorffite NiAsS is identified within the inner part of a zonal aggregate composed of heazlewoodite and galena in contact between chlorite group minerals and corundum. $\mathrm{CoO}$ content in the mineral varies up to $13 \mathrm{wt}$. \% (Table $\mathrm{S} 10$ ). The Ni- and $\mathrm{Pb}$-bearing mineralization is likely syngenetic in origin. Dravite $\mathrm{Na}\left(\mathrm{Mg}_{3}\right) \mathrm{Al}_{6}\left(\mathrm{Si}_{6} \mathrm{O}_{18}\right)\left(\mathrm{BO}_{3}\right)_{3}(\mathrm{OH})_{3}(\mathrm{OH})$ forms brownish-colored syngenetic or protogenetic crystals up to $3 \mathrm{~cm}$ in length. It lies in micaceous lenses in association with corundum and in "spinel lenses". The mineral contains lower $\mathrm{FeO}$ and $\mathrm{CaO}$ values in comparison with stoichiometric dravite; two values are up to $1.6 \mathrm{wt}$. $\%$ and $0.5 \mathrm{wt}$. \%. Rutile $\mathrm{TiO}_{2}$ forms syngenetic micro-inclusions within spinel sized up to $50 \mu \mathrm{m}$. The mineral is characterized by high tantalum content (up to $31.79 \mathrm{wt}$. \% of $\left.\mathrm{Ta}_{2} \mathrm{O}_{5}\right)$ and $\mathrm{Nb}_{2} \mathrm{O}_{5}$ values of up to 1.46 wt. \%. Hyalophane $(\mathrm{K}, \mathrm{Ba}) \mathrm{Al}(\mathrm{Si}, \mathrm{Al})_{3} \mathrm{O}_{8}$ forms likely epigenetic micro-inclusions along the fractures within the chlorite group minerals; mineral size is up to $60 \mu \mathrm{m}$. $\mathrm{BaO}$ content in hyalophane is about $6 \mathrm{wt}$. \% (Table S7). Celsian $\mathrm{Ba}\left(\mathrm{Al}_{2} \mathrm{Si}_{2} \mathrm{O}_{8}\right)$ forms lamellar epigenetic crystals and aggregates in fractures along a boundary between corundum and amesite; mineral size varies from $5 \mu \mathrm{m}$ to $30 \mu \mathrm{m}$. BaO values in mineral are up to $33.67 \mathrm{wt}$. \% (Table S7). Marialite $(\mathrm{Na}, \mathrm{Ca})_{4}\left[\mathrm{Al}_{3} \mathrm{Si}_{9} \mathrm{O}_{24}\right] \mathrm{Cl}$ forms syngenetic inclusions within chlorite group minerals sized up to $20 \mu \mathrm{m}$; $\mathrm{Cl}$ content in the mineral is about $1.7 \mathrm{wt} . \%, \mathrm{CaO}$ is $11 \mathrm{wt} . \%, \mathrm{Na}_{2} \mathrm{O}$ is about $7 \mathrm{wt}$ \% (Table S7). Pargasite $\mathrm{NaCa}_{2}\left(\mathrm{Mg}_{4} \mathrm{Al}\right) \mathrm{Si}_{6} \mathrm{Al}_{2} \mathrm{O}_{22}(\mathrm{OH})_{2}$ and tschermakite $\square\left(\mathrm{Ca}_{2}\right)\left(\mathrm{Mg}_{3} \mathrm{Al}_{2}\right)\left(\mathrm{Al}_{2} \mathrm{Si}_{6} \mathrm{O}_{22}\right)(\mathrm{OH})_{2}$ form syngeneitc micro-inclusions (up to $150 \mu \mathrm{m}$ ) within clinochlore of "spinel lenses" (Table S12). Baddeleyite $\mathrm{ZrO}_{2}$ is found as an epigenetic micro-inclusion within zircon sized up to $5 \mu \mathrm{m}$. 


\subsection{Sapphire Mineralogy, Geochemistry, and UV-Vis-NIR Spectroscopy}

Sapphires practically always form single crystals, with colorless translucent to blue transparent zones, sized up to $4 \mathrm{~cm}$ in length. Only small, less than 1ct, sapphires of gem quality can be faceted. A dark-green to black colored spinel-gahnite corona practically always surrounds sapphire crystals (Figure 2a-c). The shape of sapphire-spinel aggregates is often irregular and rounded due to numerous outgrowths of muscovite and clinoclore. Less common (in one or two lenses), there are short-prismatic and barrel-shaped sapphire crystals; however, without flat faces that are caused by intergrowth with the muscovite and spinel.

LA-ICP-MS measurements from different zones of sapphires are presented in Table 1. The position

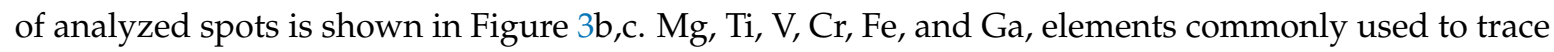
the geological origin were the only detected element of this method [14,15]. Si may also be present as a trace of sapphires; however, it cannot be measured by LA-ICP-MS due to high interference of ${ }^{27} \mathrm{AlH}^{+}$ with ${ }^{28} \mathrm{Si}^{+}$and ${ }^{28} \mathrm{SiH}$ with ${ }^{29} \mathrm{~N}-\mathrm{N}$ [16]. In the blue-colored spots, $\mathrm{Mg}$ ranges from 11 to 23 parts per million weight (ppmw), Ti ranges from 92 to 279 ppmw, $V$ from b.d.l. to 1 ppmw and $\mathrm{Cr}$ values ranges from b.d.l. to 87 ppmw (except one analyses detected 520 ppmw likely due to the ablation of diaspore inclusion; its spot was excluded from the plots provided below), relatively low Fe content (from 732 to $1021 \mathrm{ppmw}$ ), and fairly low Ga values (from 9 to $31 \mathrm{ppmw}$ ). The absorption spectra were comparable with those that were observed on sapphires of metamorphic or metasomatic origin and similar to those from Ilmen Mountains linked with syenite pegmatites [6,17]. Values of trace elements, such as $\mathrm{Mg}$, $\mathrm{Ti}$, $\mathrm{Fe}, \mathrm{Cr}, \mathrm{Ga}$, and their ratios- $\mathrm{Ga} / \mathrm{Mg}$, $\mathrm{Fe} / \mathrm{Ti}, \mathrm{Fe} / \mathrm{Mg}$, and $\mathrm{Cr} / \mathrm{Ga}$ have been used for the determination of the origin of "magmatic" versus "metamorphic" blue sapphires [14,15]. LA-ICP-MS trace element measurements of the studied sapphires showed $\mathrm{Ga} / \mathrm{Mg}<2.7, \mathrm{Fe} / \mathrm{Mg}<74, \mathrm{Cr} / \mathrm{Ga}>1.5$, and $\mathrm{Fe} / \mathrm{Ti}<9$, which is typical of sapphires of metamorphic origin [14,15]. On a Fe versus $\mathrm{Ga} / \mathrm{Mg}$ diagram and a $\mathrm{Fe}-\mathrm{Ti} \times 10-\mathrm{Mg} \times 100$ ternary plot [14], all measured corundum samples plotted in the overlapping field of "metamorphic" and "plumasitic" sapphires (Figures 6 and 7). Using the $\mathrm{FeO}-\mathrm{Cr}_{2} \mathrm{O}_{3}-\mathrm{MgO}-\mathrm{V}_{2} \mathrm{O}_{3}$ versus $\mathrm{FeO}+\mathrm{TiO}_{2}+\mathrm{Ga}_{2} \mathrm{O}_{3}$ discriminant diagram of [18], the studied sapphires plot slightly off the bottom of the overlapping area with rubies found in "mafic-ultramafic rocks" and more in the field of "metasomatic" sapphires and sapphires in "alkali basalts" (Figure 8a,b). In the discriminant factor diagram by [18], the Ilmen sapphires within meta-ultramafites are plotted to the "plumasitic" field and they are close to those from skarns, which is mostly caused by their enrichment with Ti (Figure 9). 


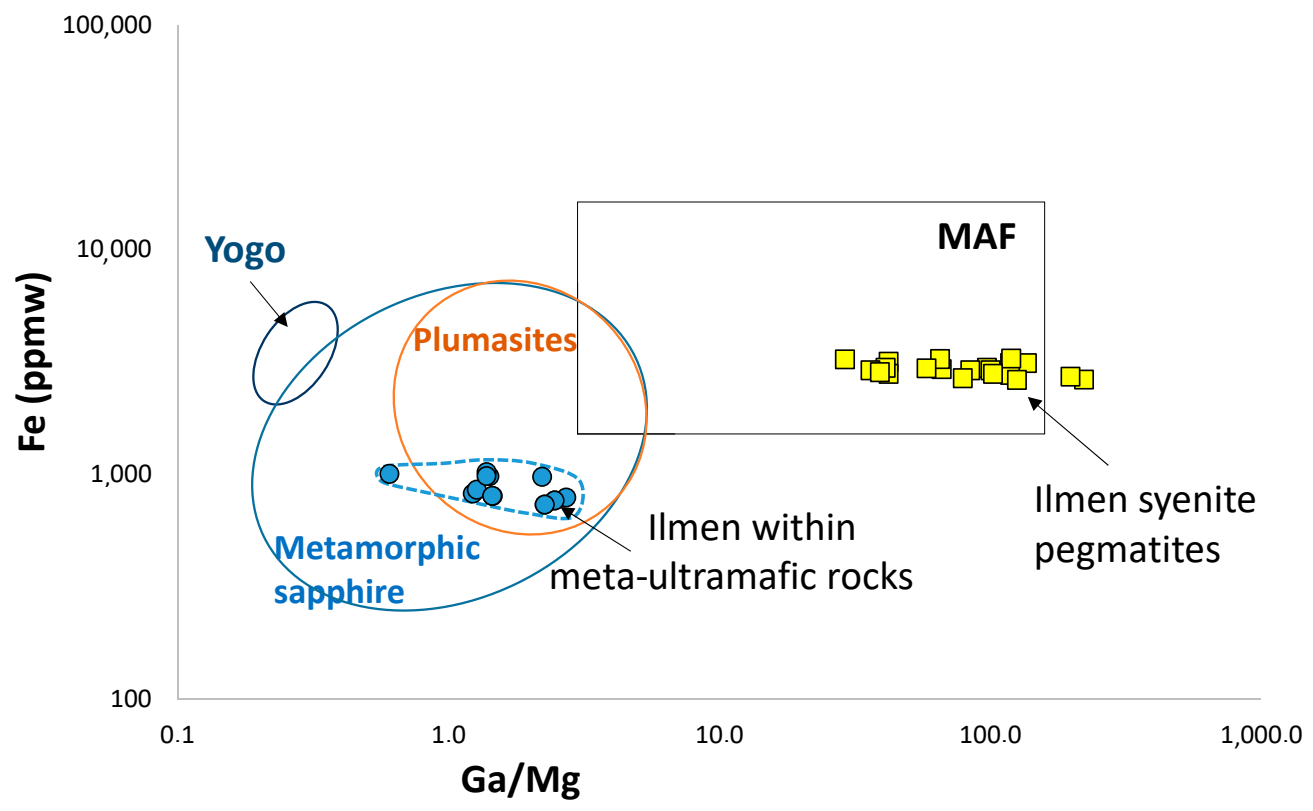

Figure 6. A plot of Ilmen sapphires within meta-ultramafic host rocks (bold blue circles) in a Fe versus $\mathrm{Ga} / \mathrm{Mg}$ diagram showing boundaries for magmatic (MAF: Main Asian Field; magmatic sapphires in alkali basalt) and metamorphic sapphires are modified after [14,19]. Ilmen sapphires that plots from syenite pegmatites is from [6].

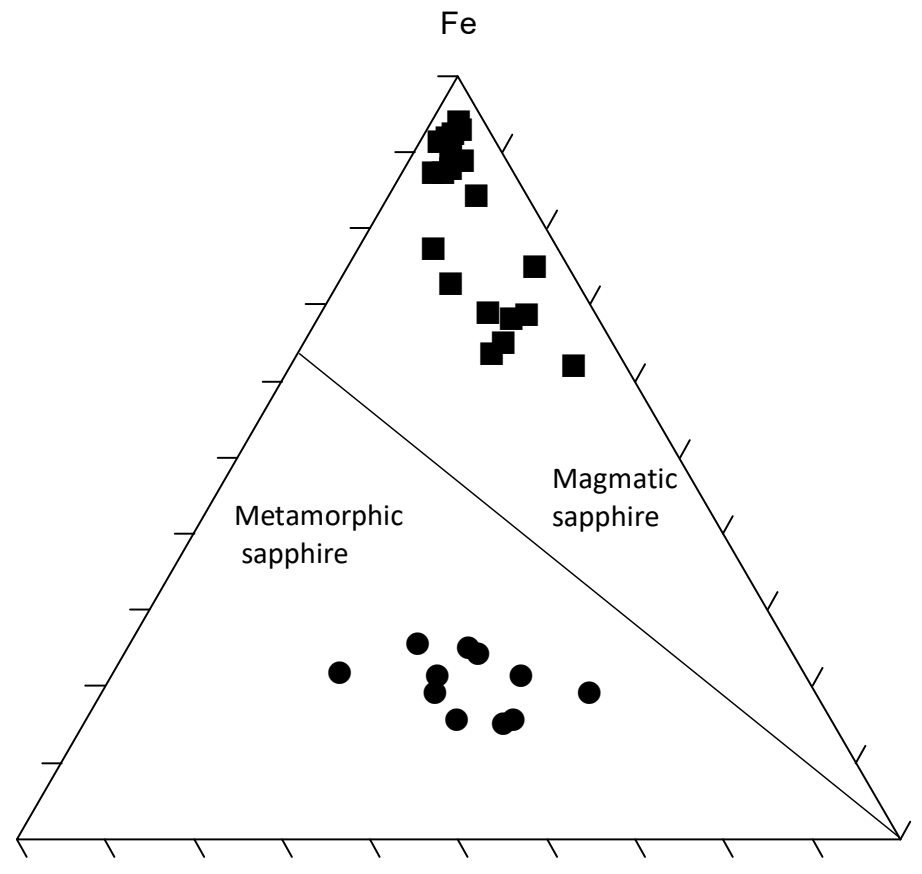

$\operatorname{Mg} \times 100$

Ti $\times 10$

Figure 7. A Fe-Mg $\times 100-\mathrm{Ti} \times 10$ ternary plot of Ilmen sapphires within ultramafic rocks (bold black circles) are modified after [14]. Values of Ilmen sapphires within syenite pegmatites (bold black squares) are from [6]). 

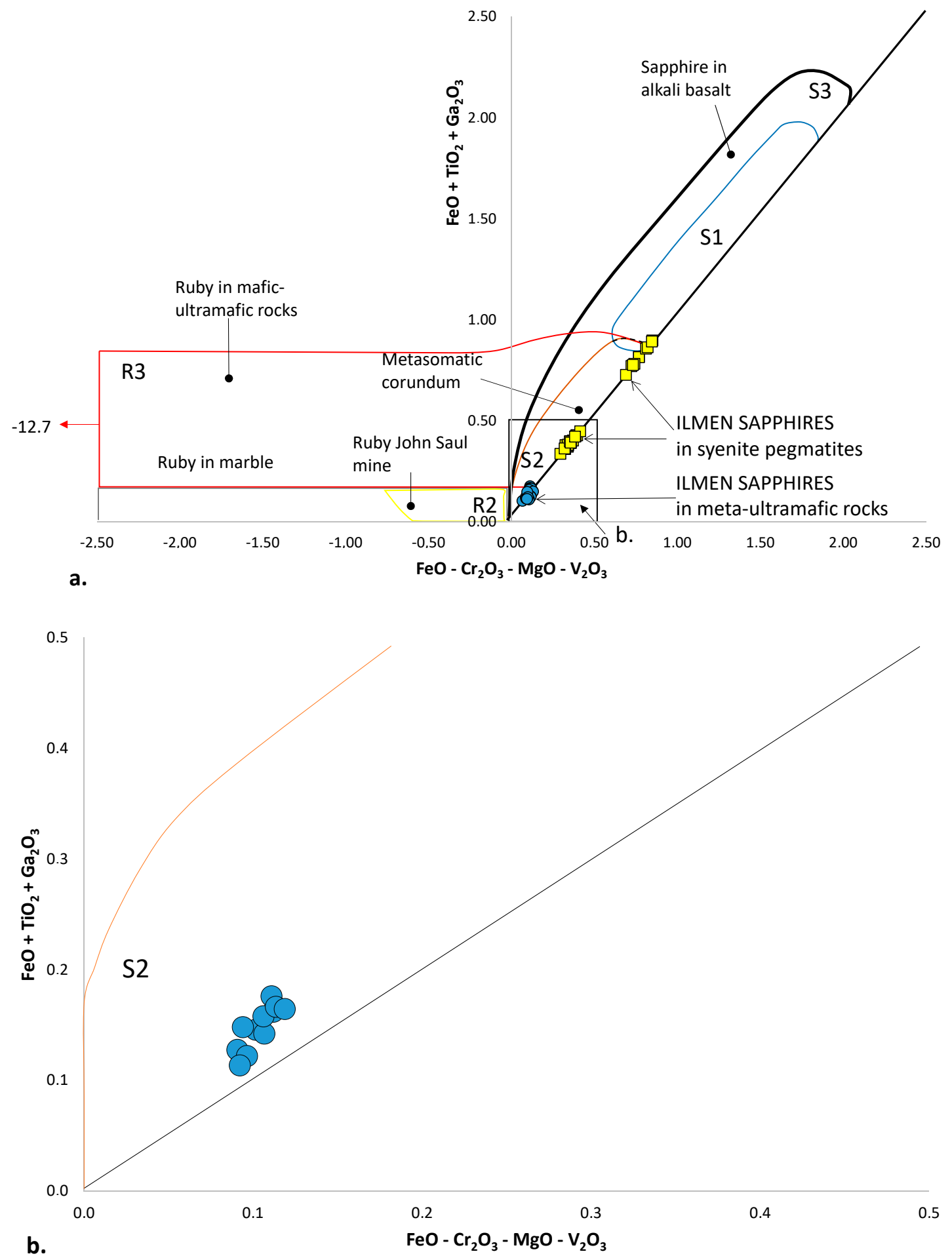

Figure 8. (a) A plot of Ilmen sapphires within meta-ultramafic rocks (bold blue circles) in a $\mathrm{FeO}-\mathrm{Cr}_{2} \mathrm{O}_{3}-\mathrm{MgO}-\mathrm{V}_{2} \mathrm{O}_{3}$ versus $\mathrm{FeO}-\mathrm{TiO}_{2}-\mathrm{Ga}_{2} \mathrm{O}_{3}$ diagram (in wt. \%) used for the geological classification of corundum deposits are modified after [18]. The main fields defined for the different types of gem corundum deposit are: John Saul Ruby Mine (Kenya) type (R2) is for ruby; for sapphire, syenitic rocks (S1); metasomatites (S2); xenocrysts in alkali basalt and lamprophyre (S3). The domains of ruby in mafic-ultramafic rocks and S2 are overlapping. Values of Ilmen sapphires within syenite pegmatites are after [6]. (b) Focus on the distribution of Ilmen sapphires within metasomatites (S2) of the plot A). 


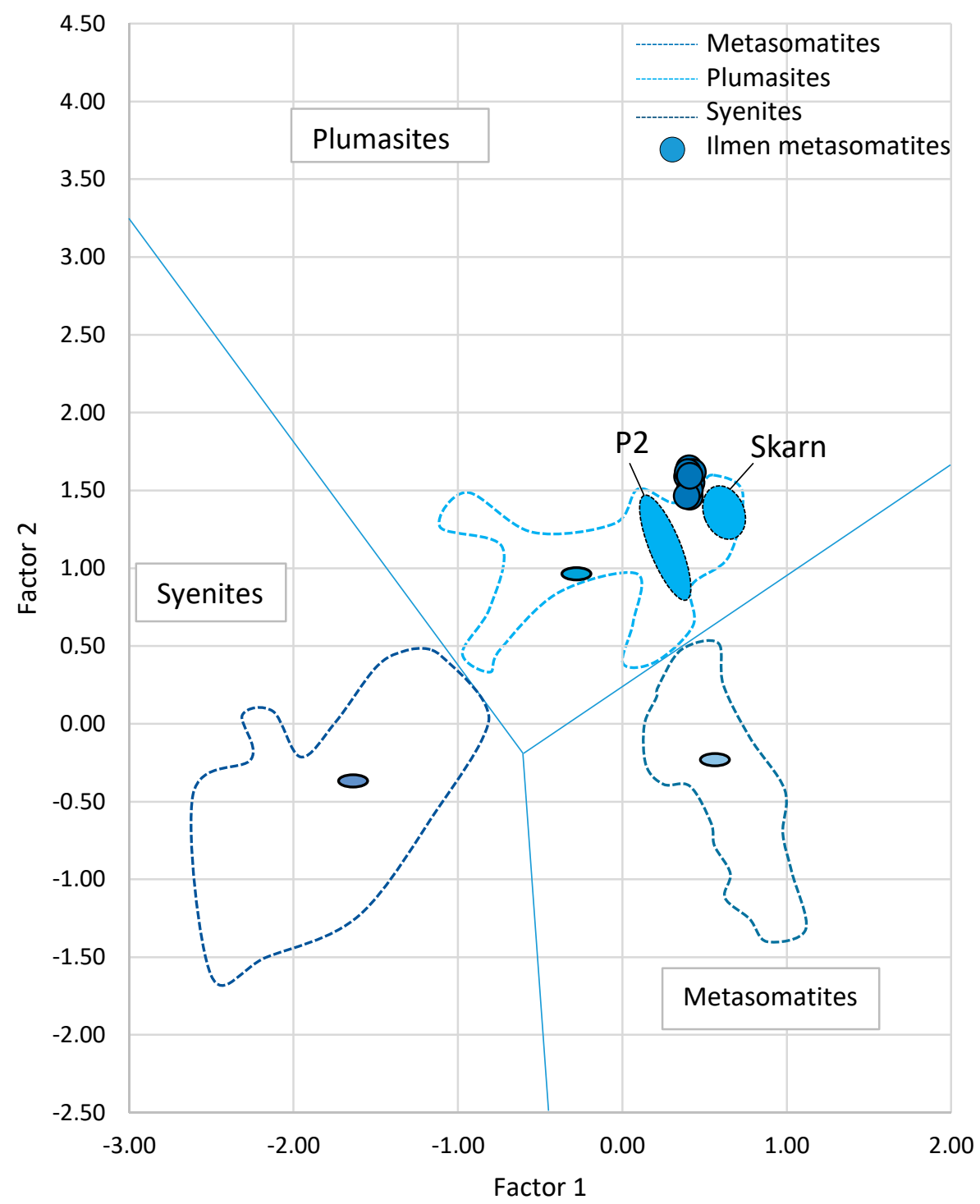

Figure 9. A plot of Ilmen sapphires within meta-ultramafic rocks (bold blue circles) in discriminant factors diagram is modified after [18]. Colored ovals are averages of syenites, plumasites, and metasomatites. P2 is an extension of metasomatic type according to [18].

\subsection{Whole-Rock Geochemistry}

EDXRF measurements of hosted meta-ultramafic and corundum-bearing rocks are presented in Table S13. According to the powder EDXRF values, meta-ultramafic host rocks have high $\mathrm{SiO}_{2}$ content up to $50-61$ wt. $\%, \mathrm{MgO}$ was about $20-32$ wt. $\%, \mathrm{CaO}$ was $0.29-17.24$ wt. $\%, \mathrm{Fe}_{2} \mathrm{O}_{3}$ was $2.9-8.2$ wt. \%, $\mathrm{Al}_{2} \mathrm{O}_{3}$ was $0.11-3.97 \mathrm{wt}$. \%, and low alkaline elements concentrations were also detected (in total, about 0.1-0.2 wt. \%). Micaceous lenses with corundum and spinel, however, showed high MgO and $\mathrm{Al}_{2} \mathrm{O}_{3}$ contents (the two are about 16-25 wt. \% and 16.26-38.52 wt. \%, respectively), combined with variable $\mathrm{SiO}_{2}$ (25-80 wt. \%), 3.44-9.5 wt. \% of $\mathrm{Fe}_{2} \mathrm{O}_{3}, 0.26-1.39$ wt. \% of $\mathrm{CaO}$, and low concentration of alkaline elements $\left(\mathrm{Na}_{2} \mathrm{O}+\mathrm{K}_{2} \mathrm{O} \leq 1 \mathrm{wt}\right.$. \%) [20]. Thus, sapphire-bearing rocks show higher $\mathrm{Al}_{2} \mathrm{O}_{3}$ and $\mathrm{K}_{2} \mathrm{O}$, however, lower $\mathrm{SiO}_{2}$ values than those detected in meta-ultramafites, but similar concentrations of $\mathrm{Na}_{2} \mathrm{O}, \mathrm{MgO}, \mathrm{CaO}$, and $\mathrm{TiO}_{2}$ (Figure 10). As for numerous metasomatic deposits, there are difficulties in the calculation of mass balance for the newly discovered sapphire-spinel-chlorite-muscovite rock, its formation occurred with significant mass-transfer. The aluminum that is required for the formation of corundum is commonly passive in weakly acidic and neutral conditions; the transfer of aluminum 
is possible in alkaline and strongly acidic conditions [21]. The mobility of aluminum in a complex with sodium was previously discussed [22]. In the case of this sapphire occurrence, $\mathrm{Al}$ was particularly mobile and it was most likely transported by fluids that are linked to miascites (Table S13 and the later discussion). Additionally, sapphire-bearing rocks were enriched with LIL-elements, such as Ba (Ba-felspars), P (apatite), and $\mathrm{Sr}$ (as a trace-element in feldspar and muscovite), which came from miascite-generated fluids as well. However, the sources of $\mathrm{Mg}$ and some siderophyle elements (Ni) are linked likely to meta-ultramafic host rocks; their parts were re-worked by metasomatic fluids.

ICP-MS measurements are shown in Table S13. The distribution of REE in micaceous lenses has the general trend-an enrichment with LREE as compared to HREE (Figure 11a). This phenomenon is possibly due to the inclusions of LREE-bearing minerals, e.g., monazite-(Ce), allanite-(Ce) or others. In the meta-ultramafic host rocks, this trend is less pronounced or it disappears: REE contents normalized to chondrite are almost the same for both LREE and HREE. Nearly all of the studied rocks show negative Eu anomalies. The REE trend of these corundum-bearing rocks is close to that observed for Ilmen corundum-bearing syenite pegmatites (Sorokina et al., unpublished data) and to that of corundum syenite pegmatites hosted by ultramafic rocks in the French Pyrénées [23]. Enrichment in HSFE was also noted (mine 418); commonly observed for alkaline-ultramafic associations of the platform type (ultramafic rocks, syenites-carbonatites etc.; [24]), and similar to those of miaskite (nepheline syenite) of the Ilmenogorsky complex. On a trace element diagram normalized to primitive mantle (Figure 11b), all studied rocks present distinct $\mathrm{K}$ and Ti negative anomalies. However, the sapphire-bearing rocks also show positive Ta and Gd anomalies, but with different $\mathrm{Sr}$ anomalies.

\section{5. $\mathrm{Rb}$-Sr and Sm-Nd Isotope Measurements}

$\mathrm{Rb}-\mathrm{Sr}$ and $\mathrm{Sm}-\mathrm{Nd}$ isotope measurements of sapphire-bearing rocks 418-12 and 418-13 previously analyzed by EDXRF and ICP-MS are presented in Table S14. As well, two samples of 418-13 rock containing feldspar and two samples of mica extracted from appropriated rock sample 418-13 associated with sapphire mineralization were analyzed in order to constrain the $\mathrm{Rb}-\mathrm{Sr}$ age. Obtained values of $\mathrm{Rb}, \mathrm{Sr}, \mathrm{Sm}$, and $\mathrm{Nd}$ by TIMS are closely similar or comparable to those that were received by ICP-MS (Tables S12 and S13). ${ }^{87} \mathrm{Sr} /{ }^{86} \mathrm{Sr}$ for samples $418-12$ and $418-13$ are varied from $0.708764 \pm 0.000010(2 \sigma)$ to $0.710587 \pm 0.000006(2 \sigma)$. For mica samples, these values are higher and vary from $0.711371 \pm 0.000008$ to $0.714131 \pm 0.000016$. The calculated $\mathrm{Rb}$-Sr isochrone age for three rock samples and mica-2 sample is $289.3 \pm 8.7 \mathrm{Ma}(2 \sigma), \mathrm{MSWD}$ is 4.1 (Figure 12). Note, the calculated Rb-Sr age for another mica sample (mica-1) with three rock samples gave much higher error (352 $\pm 35 \mathrm{Ma})$ and higher MSWD (72), which was likely due to the secondary alteration of muscovite samples mica- 1 . $\left({ }^{87} \mathrm{Sr} /{ }^{86} \mathrm{Sr}\right)_{289}$ of all samples recalculated on $289 \mathrm{Ma}$ are about 0.707351 to $0.707919 .{ }^{143} \mathrm{Nd} /{ }^{144} \mathrm{Nd}$ for the samples 418-12 and 418-13 are $0.5122 \pm 0.000008(2 \sigma)$ and $0.5122 \pm 0.000012(2 \sigma), \varepsilon \mathrm{Nd}_{(289 \mathrm{Ma})}$ is -7.8 . The obtained high ${ }^{87} \mathrm{Sr} /{ }^{86} \mathrm{Sr}$ ratios and low $\varepsilon \mathrm{Nd}$ correspond to the formation of the newly discovered corundum-bearing rocks under the significant influence of crustal fluids. 


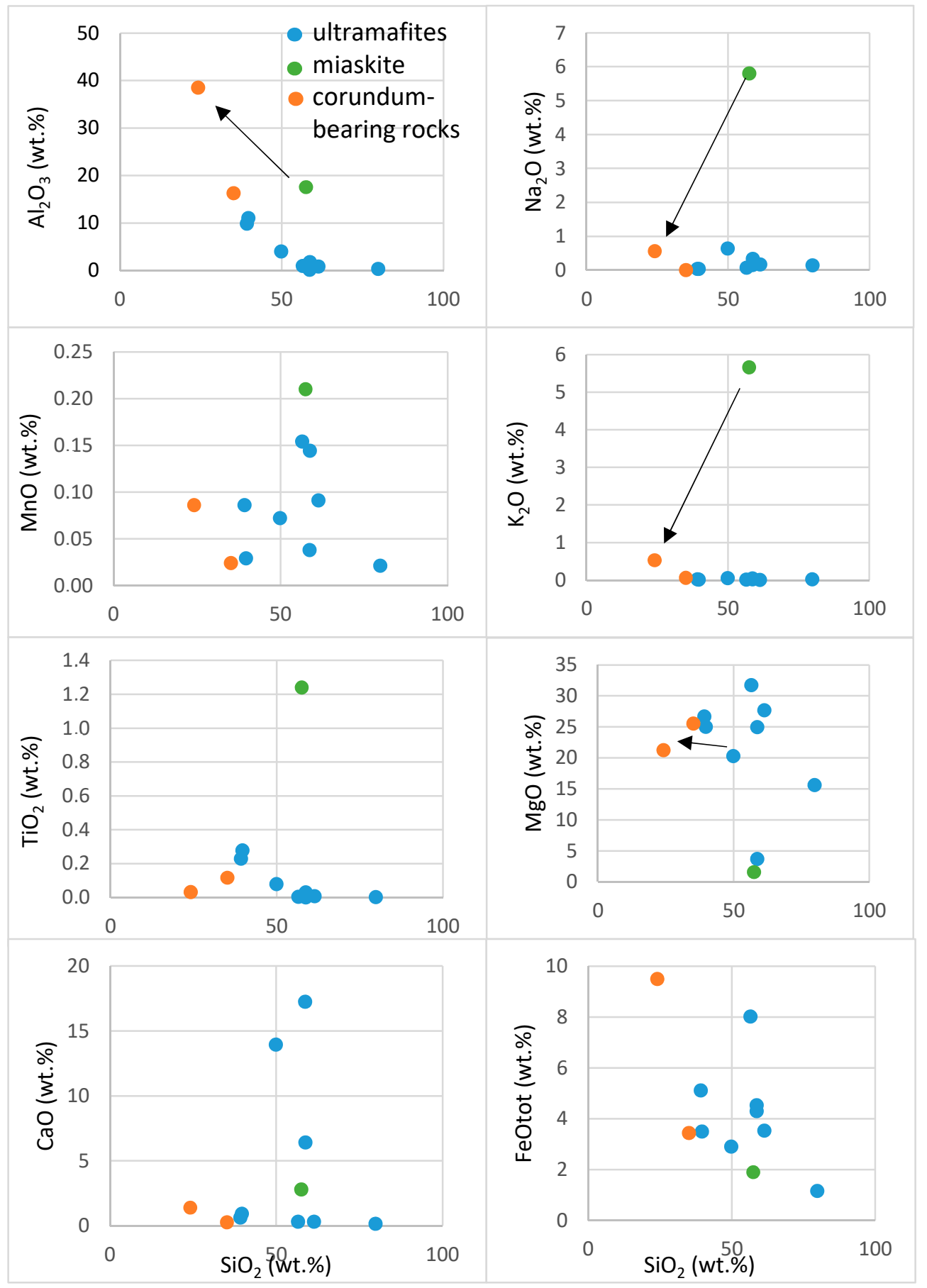

Figure 10. Variations of selected elements in whole-rock compositions from Table S13. Black arrows show the source of major elements of metasomatites. Chemistry of miascite is after [25]. 


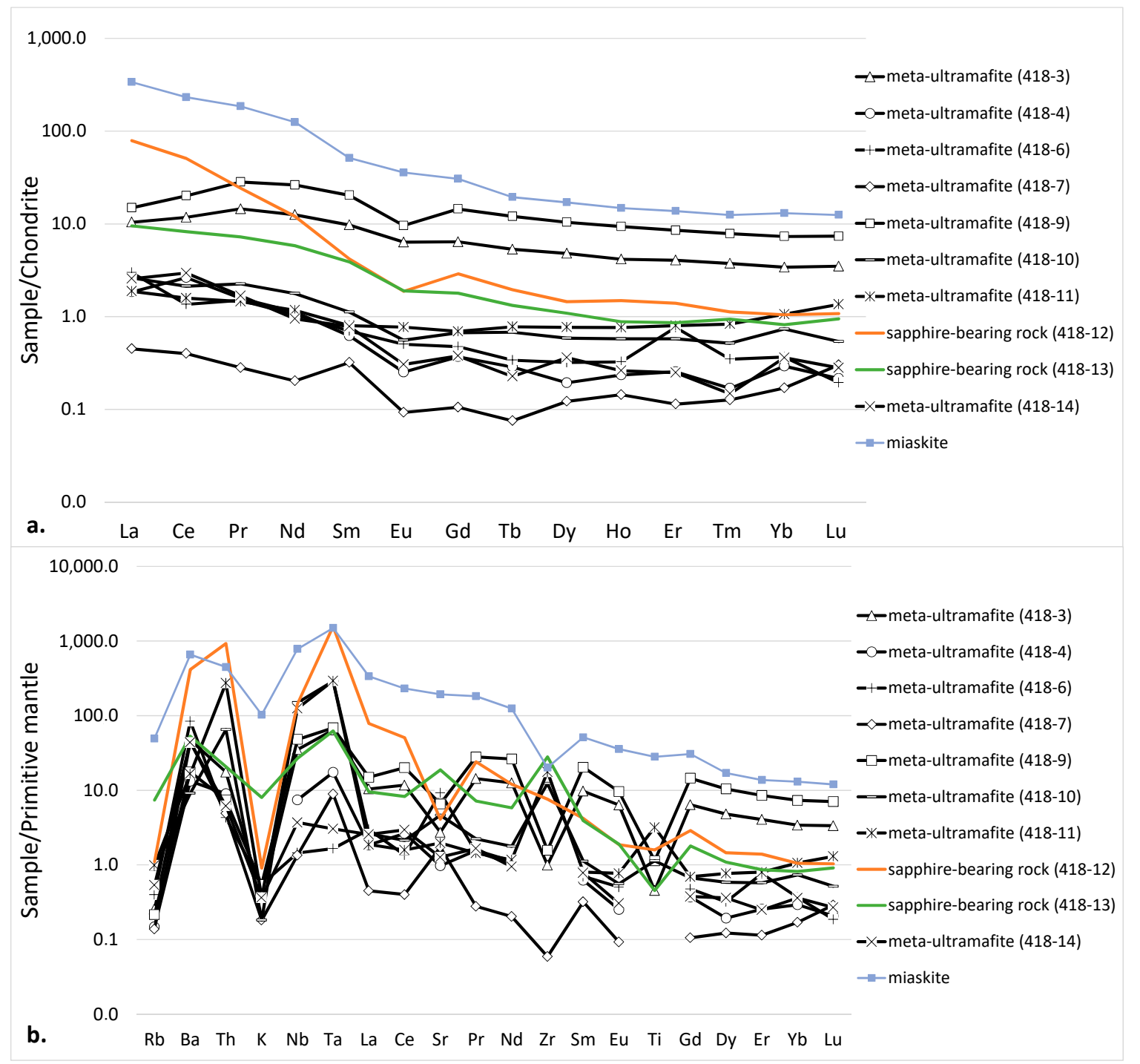

Figure 11. (a) Chondrite-normalized REE diagram of selected samples, the chondrite REE data are after [26]; (b) Trace elements diagram of selected samples normalized to primitive mantle, data on trace elements in primitive mantle are after [26]. Chemistry of miascite is after [25]. 


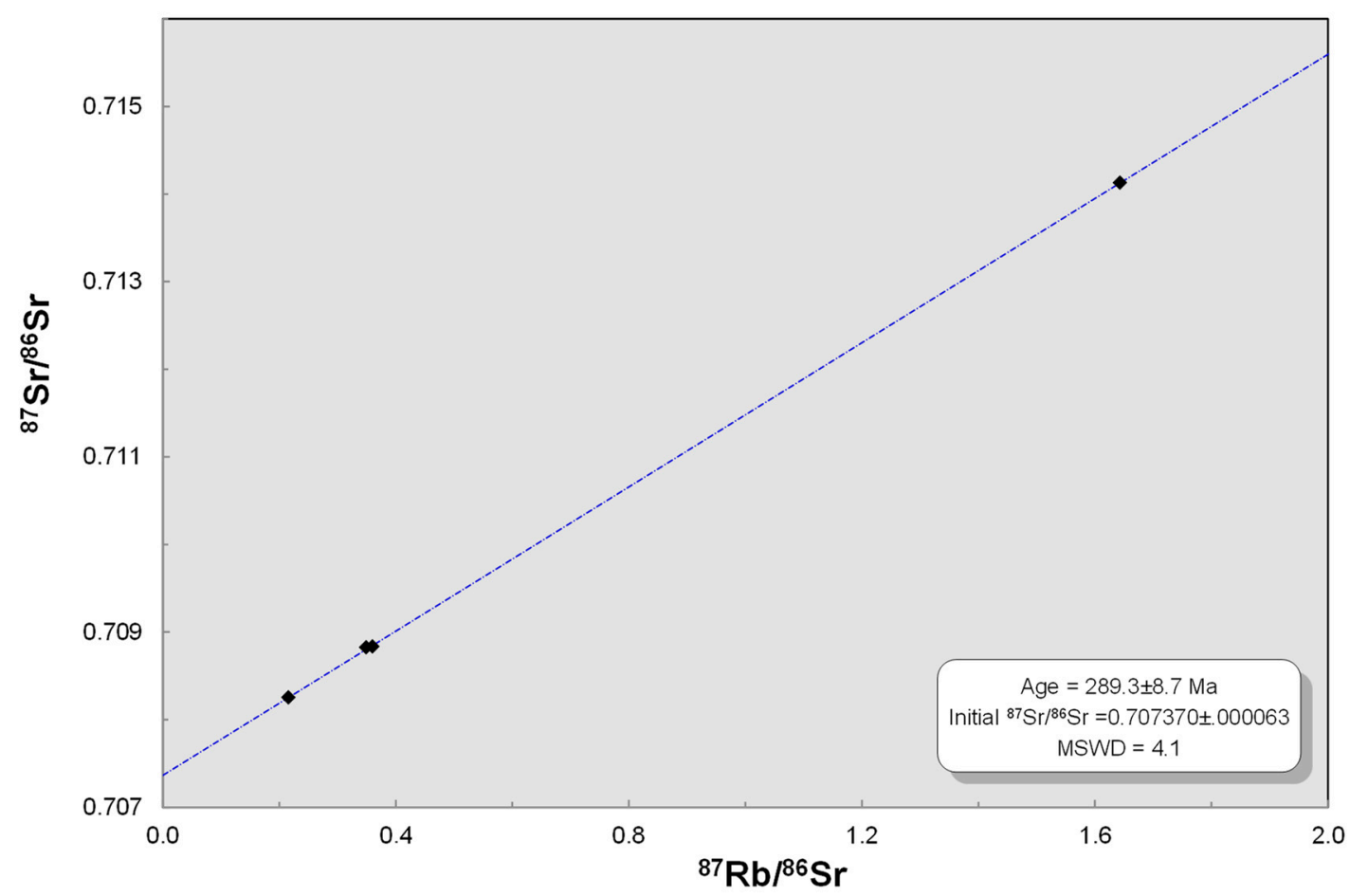

Figure 12. The Rb-Sr isochrone for three sapphire-bearing rocks and one muscovite samples associated with sapphire of 418 mine in Ilmen Mountains are with yielded age at 289.3 $\pm 8.7 \mathrm{Ma}(2 \sigma)$, MSWD is 4.1.

\section{Discussion}

\subsection{Suggested Petrogenesis of Sapphire in the Meta-Ultramafic Host Rocks of the Ilmen Mountains}

The studied blue sapphires surrounded by spinel coronas embedded in chlorite-muscovite matrix present metasomatites that are found within meta-ultramafic host rocks. These host rocks are most likely formed after metasomatic alteration (serpentinization) of orthopyroxenites; i.e., containing orthopyroxene with minor olivine and clinopyroxene. While the orthopyroxenites were formed at about $1.3 \mathrm{Ga}$ and are related to the Saitovsky series of Kyshtimsky strata of the Ilmenogorsky complex, $\mathrm{Rb}-\mathrm{Sr}$ and $\mathrm{Sm}-\mathrm{Nd}$ isotopic data indicate their linkage with enriched mantle domains of types EM1 and EM2 [27].

The metasomatism required for the formation of these rocks with blue sapphires took place around $289.3 \pm 8.7 \mathrm{Ma}$ (measured by $\mathrm{Rb}$-Sr dating of sapphire-bearing rocks and mono-mineral muscovite associated with sapphires). This age represents the cooling age after the metamorphic peak (transpression) that occurred in the Ilmenogorsky complex at about 330-320 Ma during the Uralian orogeny [28]. The metasomatic fluids formed after the partial melting of miascites occurred in the region (440-420 Ma). These fluids were also the source of HFSE, LILE, and alumina (remobilized under alkaline conditions [21,22]) needed for corundum formation, and transported these chemical elements at a minimum distance of about $4 \mathrm{~km}$ (calculated from the eastern flank of Ilmenogorsky complex) reaching the meta-ultramafic rocks. In Figure 11, similar REE trends between miascites and corundum-bearing rocks in mine 418 are presented (i.e., enrichment of LREE as compared to HREE), which is an important evidence of the metasomatic fluid source. Partial melting of miascites is associated with the formation of migmatities with more acidic composition from albitites to even granites. In the Ilmenogorsky miascite massif, alumina remobilization can also be associated with the formation of zeolitic veins and zeolitizated zones of pegmatites, filling late-forming zones with aluminum hydroxides (gibbsite, nordstrandite, boehmite, diaspore).

Desilication also took place during the contact of fluids with ultramafic rocks and sapphire formation. Desilication is commonly observed during corundum crystallization in numerous deposits 
worldwide ([1,29,30], etc.). The importance of buffering capacity of ultramafic host rocks with respect to silica in the Greenland ruby deposit has been previously shown [31]. In this deposit, the meta-ultramafic host rocks show similar buffering capacity in respect to the desilication of Al-bearing alkaline fluids that are linked to miascites. Initial ultramafic rocks are also most likely the source of $\mathrm{Mg}$ required for spinel and chlorite formation found in metasomatites linked with the corona around the sapphires, as well as the source of $\mathrm{Ni}$ for nickel-bearing minerals.

Sapphire crystallization was likely caused by the breakdown of diaspore possibly by the following reaction: 2diaspore $\rightarrow$ corundum $+\mathrm{H}_{2} \mathrm{O}$. Note, diaspore formed in meta-ultramafic host rock likely due to a previous metasomatic event that is linked with the partial melting of miascites. A previous metasomatic event was likely a significant time before the deposition of sapphire-bearing metasomatites. Chlorite formation occurred during the metasomatic reworking of meta-ultramafic host rocks. Meanwhile, the spinel corona most likely formed as a consequence of metasomatic fluid-chlorite interactions with the corundum as a reaction rim. Under decreasing pressure and temperature, muscovite crystallized during the breakdown of corundum: corundum + orthoclase + $\mathrm{H}_{2} \mathrm{O} \rightarrow$ muscovite; previously observed for a corundum-mica-tourmaline rock hosted by ultamafites of New Zealand [32].

Experiments have shown that blue sapphires (incorporation of Ti and Fe into the corundum lattice) can be formed at around $700{ }^{\circ} \mathrm{C}$ after muscovite and biotite, along with a peraluminous silicic melt at $2 \mathrm{kbar}$ (water pressure) [33]. Corundum and hercynite spinel also coexist with orthoclase-rich feldspar and biotite at $750{ }^{\circ} \mathrm{C}$ [33]. Besides, other experiments have shown that muscovite can still be stable, slightly above $700{ }^{\circ} \mathrm{C}$ and at about 1.8 kbar [34] (Figure 13a). Thus, it seems that sapphire-spinel-clinochlore-muscovite metasomatites formed at a temperature around $700-750{ }^{\circ} \mathrm{C}$ and pressure about 1.8-3.5 kbar; at the eutectic point of corundum + orthoclase $+\mathrm{H}_{2} \mathrm{O} \leftrightarrow$ muscovite; where the three minerals are in equilibrium (Figure 13b).
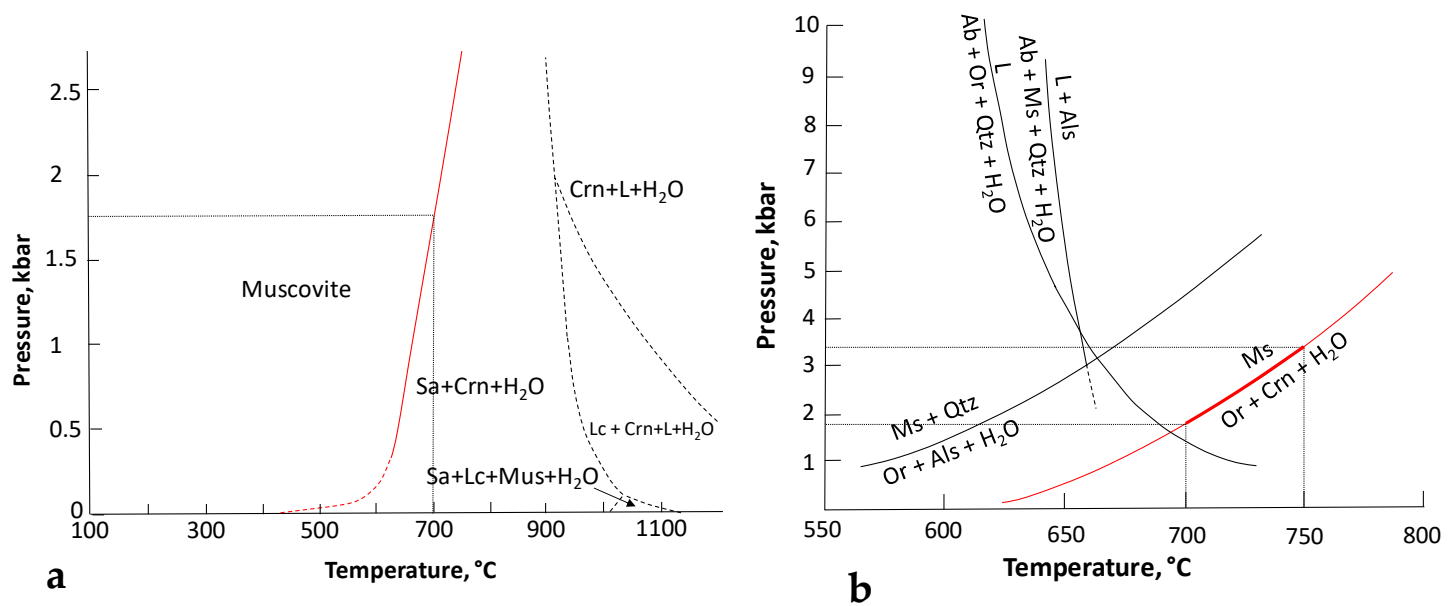

Figure 13. (a) The equilibrium curve (solid and dash) for the reaction Sa (sanidine) $+\mathrm{Crn}+\mathrm{H}_{2} \mathrm{O} \leftrightarrows$ Mus, estimates of the equilibrium curve for the melting of sanidine and leucite- $\mathrm{Lc}$ (dash) in the muscovite composition, and possible relations between the assemblages $\mathrm{Sa}+\mathrm{Crn}+\mathrm{H}_{2} \mathrm{O}$ and $\mathrm{Mu}+\mathrm{Sa}+\mathrm{Lc}+$ $\mathrm{H}_{2} \mathrm{O}$ are modified after [34]. (b) Phase relations in peraluminous granitic systems in terms of pressure and temperature after [35]. The dashed line is a metastable extension of the reaction $\mathrm{Ab}$ (albite) $+\mathrm{Ms}$ (muscovite) + Qtz (quartz) $+\mathrm{H}_{2} \mathrm{O}=$ melt + aluminum silicate to 2 kbar pressure. The $\mathrm{H}_{2} \mathrm{O}$-saturated haplogranite solidus $\left(\mathrm{Ab}+\mathrm{Or}\right.$ (orthoclase) $+\mathrm{Qtz}+\mathrm{H}_{2} \mathrm{O}=$ melt) and the subsolidus second sillimanite isograd $\left(\mathrm{Ms}+\mathrm{Qtz}=\mathrm{Or}+\right.$ aluminum silicate $\left.+\mathrm{H}_{2} \mathrm{O}\right)$ were determined by [36] and [37]. The terminal muscovite reaction $\mathrm{Ms}=\mathrm{Or}+\mathrm{Crn}+\mathrm{H}_{2} \mathrm{O}$ comes from [35]. The diagram was modified after [33]. 


\subsection{Comparison with Sapphire and Ruby from Metasomatites}

To date, only pink sapphires to rubies (probably none of them of gem quality) were found in metasomatites within the ultramafic host rocks; e.g., they are known in the eastern Transvaal [38] and in the Barberton greenstone belt [39] of South Africa, in Zimbabwe [40], and in Westland, New Zealand [32]. Ruby-fuchsite rock, 'verdite' from Zimbabwe is enriched in Nias represented by gersdorfitte (NiAsS), which is also the case of the described occurrence in the Ilmen Mountains, in which andalusite, chlorite, margarite, tourmaline, diaspore, rutile, and native Bi are present as well. However, in Zimbabwe, 'verdite', which occurs in bodies a few kilometers length, was formed as the result of post-volcanic, pre-metamorphic exhalative alteration of komatiitic lavas [41]. Another approach to the genesis of 'verdite' suggests an alteration of ultramafic rocks in a high-temperature low-pH hydrothermal solution carrying LILE [42]. Ruby-bearing boulders of metasomatic origin from Westland in New Zealand, as is the case of the described occurrence, are found embedded in micaceous matrix associated, however, with fuchsite, margarite, and tourmaline [32]. In New Zealand, similarly to the described Ilmen sapphire occurrence, the crystallization of minerals in association with corundum required significant mass-transfer during the metasomatic process, possibly 50-90\% [32]. Regionally metamorphosed pink sapphire to ruby deposits within an ultramafic protolith in Paranesti in Greece were also reported [43]. In common with the Ilmen sapphires, the Paranesti rubies are characterized by spinel-picotite inclusions. Spinel inclusions and Ni-bearing sulfides were also found within sapphires from some Australian occurrences [44]. However, the spinel inclusions in these sapphires are more Co-rich than Zn-rich, as is the case in the present Ilmen sapphires (Table S5). An inclusion of Zn-rich spinel within sapphire is also reported from a placer in Kedrovka, in the Russian Far East [45].

\subsection{Comparison of Chemical Data with Sapphires from Other Geological Environments}

In a $\mathrm{Fe}$ versus $\mathrm{Ga} / \mathrm{Mg}$ diagram [14], all measured corundum samples were plotted to "metamorphic" and "plumasitic" population fields (Figure 6), clearly away from the "magmatic" blue sapphires that are found within syenite pegmatites of Ilmen Mountains (see again [6,17]). However, these trace-element diagrams should be used with the caution and possibly revised, since it was found that some of the sapphires from magmatic deposits could be plotted in the "metamorphic field" [46,47]. It is probably important to refine these plots using solely data of gem-quality samples and to group them by color (e.g., plot sapphire and rubies separately), taking into account that most of trace elements used for these are corundum chromophores (e.g., Fe, $\mathrm{Ti}, \mathrm{Mg}, \mathrm{Cr}, \mathrm{V}$ ). For instance, as shown in Figure $\mathrm{S1}$, the population field is more scattered when plotting colorless opaque sapphires together with those of blue color.

On the $\mathrm{FeO}-\mathrm{Cr}_{2} \mathrm{O}_{3}-\mathrm{MgO}-\mathrm{V}_{2} \mathrm{O}_{3}$ versus $\mathrm{FeO}+\mathrm{TiO}_{2}+\mathrm{Ga}_{2} \mathrm{O}_{3}$ discriminant diagram (Figure 8), the plot is slightly away from the area with rubies in "mafic-ultramafic rocks" and is mostly in the field with "metasomatic" sapphires and sapphires in "alkali basalts". The UV-Vis-NIR spectra of studied sapphires were comparable to those that were observed on sapphires of metamorphic or metasomatic origin.

\section{Conclusions}

Most gem-quality sapphires are mined from placers of unclear primary and possibly diverse origins. Studies of gem-quality sapphires that are found in situ within host rocks may provide clues to the petrogenesis of those found in secondary occurrences.

Gem-quality sapphire is known from syenite pegmatites in the Ilmen Mountains of the South Urals. An occurrence of gem-quality sapphires from these mountains was also discovered within meta-ultramafites where sapphires form concentric aggregates within spinel-gahnite coronas. Sapphires form irregular-shaped translucent to transparent crystals with colorless and blue zones. The concentric sapphire aggregates with spinel coronas are embedded in a clinochlore-muscovite matrix. In this occurrence, corundum(sapphire)-spinel(gahnite)-clinochlore-muscovite aggregates 
associate with anorthite $\left(\mathrm{An}_{100}\right)$, apatite, zircon, diaspore, microlite, allanite-dissakisite-(Ce), monazite-(Ce), dravite, Ba-feldspars, and various Ni-bearing minerals. The mantle-generated ultramafic host rocks (orthopyroxenites) that are composed of enstatite with minor olivine have undergone significant serpentinization. Altered meta-ultramafic host rocks have high contents of $\mathrm{SiO}_{2}$ (approximately 50-61 wt. \%) and $\mathrm{MgO}$ (approximately 20-32 wt. \%), but low $\mathrm{Al}_{2} \mathrm{O}_{3}(0.11-3.97 \mathrm{wt}$. \%), as well as alkaline elements concentrations (in total, about 0.1-0.2 wt. \%), whereas the sapphire-bearing rocks showed high $\mathrm{MgO}$ (16-25 wt. \%) and high $\mathrm{Al}_{2} \mathrm{O}_{3}$ (16.26-38.52 wt. \%) contents combined with variable $\mathrm{SiO}_{2}\left(25-80 \mathrm{wt}\right.$. \%), but low concentrations of alkaline element $\left(\mathrm{Na}_{2} \mathrm{O}+\mathrm{K}_{2} \mathrm{O} \leq 1 \mathrm{wt}\right.$. \%). Most of the sapphire-bearing rocks - in contrast with the meta-ultramafic host rocks-are enriched in LREE and depleted in HREE with negative Eu anomalies. Spider REE diagrams of the studied samples are similar to those of sapphires in the syenite pegmatites, linked to intrusions of miascites (nepheline syenite) in the Ilmen Mountains. Sapphire-spinel-clinochlore-muscovite rock formed after metasomatic alteration of orthopyroxenites at a temperature around $700-750{ }^{\circ} \mathrm{C}$ and pressure about 1.8-3.5 kbar. The metasomatic fluids enriched in HFSE, LILE, and alumina formed after the partial melting of miascites (nepheline syenites), while $\mathrm{Mg}$ and some siderophile elements (Ni) came from mantle-generated meta-ultramafic host rocks. Formation of this metasomatic rock occurred at about $289 \pm 9 \mathrm{Ma}(\mathrm{Rb}$-Sr dating of sapphire-bearing rocks and mono-mineral muscovite associated with sapphires), representing the cooling ages after the peak metamorphism at about 330-320 Ma during the Uralian orogeny.

Sapphire crystallized after the breakdown of diaspore by the reaction: 2 diaspore $\rightarrow$ corundum + $\mathrm{H}_{2} \mathrm{O}$. Chlorite occurred during the metasomatic reworking of meta-ultramafic host rocks. However, the spinel corona surrounding sapphire aggregates most likely formed as a consequence of metasomatic fluid-chlorite interactions with the corundum. Under decreasing pressure and temperature, muscovite crystallized during the breakdown of corundum by the reaction: corundum + orthoclase $+\mathrm{H}_{2} \mathrm{O}$ $\rightarrow$ muscovite.

Despite on obvious metasomatic genesis, LA-ICP-MS analyses of blue sapphires showed Ga/Mg $<2.7, \mathrm{Fe} / \mathrm{Mg}<74, \mathrm{Cr} / \mathrm{Ga}>1.5$, and $\mathrm{Fe} / \mathrm{Ti}<9$, in the range of "metamorphic" sapphires. The Fe versus $\mathrm{Ga} / \mathrm{Mg}$ diagram and Fe-Ti $\times 10-\mathrm{Mg} \times 100$ ternary plot should be used with the caution and possibly revised using solely data of gem-quality samples and to group them by color.

Supplementary Materials: The following are available online at http:/ /www.mdpi.com/2075-163X/9/1/36/s1, Table S1: Description of sapphire-spinel samples used for WDS EMPA and LA-ICP-MS, Table S2: Mineral assemblage and mode of minerals in the thin-sections, Table S3: Minerals identified in association with the sapphire, Table S4: Texture relationship of minerals found in association with sapphire, Table S5: Chemical composition of spinel and gahnite, Table S6: Chemical composition of muscovite and clinochlore, Table S7: Chemical composition of feldspar group minerals and marialite, Table S8: Chemical composition of apatite group minerals, Table S9: Chemical composition of zircon and monazite-(Ce), Table S10: Chemical composition of sulphide minerals, Table S11: Chemical composition of allanite-(Ce) group minerals, Table S12: Chemical composition of amphibole group minerals, Table S13: EDXRF (wt. \%) and ICP-MS (ppmw) analyses of host rocks from 418 mine, Table S14: Rb-Sr and Sm-Nd isotope measurements of corundum-bearing rocks. Figure S1: A plot of Ilmen sapphires within meta-ultramafic host rocks (blue-colored samples-bold blue circles, colorless samples-colorless circles) in a Fe versus Ga/Mg diagram showing boundaries for magmatic (MAF: Main Asian Field; magmatic sapphires in alkali basalt) and metamorphic sapphires, modified after [14,18].

Author Contributions: E.S.S. formulated the idea of a paper, collected the samples for studying, conducted a research on the Raman spectroscopy, LA-ICP-MS, and TIMS, and their following data-reduction process, designed EDXRF and WDS EMPA experiments, assembled some tables and figures, and wrote the manuscript; M.A.R. collected the samples for host rock studying, performed the petrography of corundum-bearing and host rocks, designed the EDS EMPA and ICP-MS experiments, assembled some tables and figures, provided the field data and mineralogy of host rocks; S.N.N. performed the petrography of host rocks and provided the geological setting data; S.K. helped with data interpretation and editing of the manuscript; N.N.K. performed WSD EMPA of selected samples; A.G.N. carried out UV-Vis-NIR spectroscopy of sapphires and provided its interpretation; M.O.A. assisted with LA-ICP-MS measurements and data-reduction process; A.V.S. assisted with both sample preparation process for TIMS and TIMS measurements; Y.A.K. created some ideas for TIMS measurements and interpretation of final TIMS data; V.A.K. performed the EDS EMPA measurements.

Funding: The research has been supported by the Council on grants of the President of the Russian Federation (project no. MK-4459.2018.5); the Raman measurements and field trip to Ilmen State Reserve in 2016 were 
supported by Gemological Institute of America through the R.T. Liddicoat Postdoctoral Research Fellowship for one author (ESS); UV-Vis-NIR measurements were supported by Russian Government Program of Competitive Growth of Kazan Federal University.

Acknowledgments: The work in the Ilmen Natural Reserve was conducted under an agreement on scientific collaboration between the GEOKHI RAS and the Ilmen Natural Reserve. The samples used in this study were transferred by the Ilmen State Reserve for scientific purposes. The authors thank the Editor of Minerals and Guest Editors for invitation to submit the manuscript for consideration and possible contribution in a special issue on "Mineralogy and geochemistry of gems". Pautov L.N. and Agakhanov A.A. (Fersman Mineralogical Museum RAS), Phillipova K.A. (Institute of Mineralogy Ural branch of RAS), and Medvedeva E.V. (Ilmen State Reserve Ural branch RAS) helped with electron-microprobe, ICP-MS measurements, and consultations on the topic of research. Kuz'mina T.G., Romashova T.V., Smirnov V.I., and Turkov V.A. (GEOKHI RAS) assisted in sample preparation process and EDXRF measurements. We are thankful to John Saul (Swala Gem Traders, Tanzania), four anonymous reviewers, and Guest Editor of this special issue Panagiotis Voudouris for improving the text of an earlier version of this article.

Conflicts of Interest: The authors declare no conflict of interest.

\section{References}

1. Barbot-de-Marni, P.N. About a new deposit of zircon, tantalite and corundum. Min. J. 1828, 3, 171-172. (In Russian)

2. Polyakov, V.O.; Bazhenov, A.G.; Petrov, V.I. Mineral associations of corundum of the Ilmen Mountains. In New Data on the Mineralogy of Endogenous Deposits and Zones of Technogenesis in the Urals; Ural Branch RAS: Sverdlovsk, Russia, 1991; pp. 15-21.

3. Giuliani, G.; Ohnenstetter, D.; Fallick, A.E.; Groat, L.; Fagan, A.G. The geology and genesis of gem corundum deposits. In Geology of Gem Deposits, 2nd ed.; Groat, L.A., Ed.; Mineralogical Association of Canada Short Course Series; Mineralogical Association of Canada: Tucson, AZ, USA, 2014; Volume 44, pp. $29-112$.

4. Lennikh, V.I.; Valizer, P.M. To the geological scheme of the Ilmenogorsky complex. In Geology and Mineralogy of the Ilmenogorsky Complex: Situation and Problems; Ilmen State Reserve Ural Branch RAS: Miass, Russia, 2006; pp. 20-27. (In Russian)

5. Krasnobaev, A.A.; Puzhakov, B.A.; Petrov, V.I.; Busharina, S.V. Zirconology of metamorphites of the Kyshtym-Arakulian strata of the Sysert-Ilmenogorsky complex. Proc. Zavaritsky Inst. Geol. Geochem. (Trudy Instituta Geologii i Geokhimii im. Akademika A.N. Zavaritskogo) 2009, 156, 264-268.

6. Sorokina, E.S.; Karampelas, S.; Nishanbaev, T.P.; Nikandrov, S.N.; Semiannikov, B.S. Sapphire Megacrysts in Syenite Pegmatites from the Ilmen Mountains, South Urals, Russia: New Mineralogical Data. Can Mineral. 2017, 55, 823-843. [CrossRef]

7. Medvedeva, E.V.; Rusin, A.I.; Murdasova, N.M.; Kotlyarov, V.A. Mineralogy of andalusite-kyanite-sillimanite rocks of the Saitovsky series in Ilmeny Mountains, the South Urals. Zapiski RMO 2012, 141, 50-60. (In Russian)

8. Korinevsky, E.V. Chaotic Formations of the Ilmenogorsky Metamorphic Complex of the Southern Urals and Their Nature; Ural Branch RAS: Ekaterinburg, Russia, 2013; p. 112. (In Russian)

9. Jochum, K.P.; Weis, U.; Stoll, B.; Kuzmin, D.; Yang, Q.; Raczek, I.; Jacob, D.E.; Stracke, A.; Birbaum, K.; Frick, D.A.; et al. Determination of reference values for NIST SRM 610-617 glasses following ISO Guidelines. Geostand. Geoanal. Res. 2011, 35, 397-429. [CrossRef]

10. Jochum, K.P.; Scholz, D.; Stoll, B.; Weis, U.; Wilson, S.A.; Yang, Q.; Schwalb, A.; Börner, N.; Jacob, D.E.; Andreae, M.O. Accurate trace element analysis of speleothems and biogenic calcium carbonates by LA-ICP-MS. Chem. Geol. 2012, 318-319, 31-44. [CrossRef]

11. Ludwig, K.R. Isoplot/Ex: A Geochronological Toolkit for Microsoft Excel; Special Publication No. 1a (rev. 3); Berkeley Geochronology Center: Berkeley, CA, USA, 2004.

12. Whitney, D.L.; Evans, B.W. Abbreviations for names of rock-forming minerals. Am Mineral. 2010, 95, $185-187$. [CrossRef]

13. Nikandrov, S.N.; Rassomakhin, M.A.; Nishanbaev, T.P. List of minerals of Ilmen Mountains (data for 2017). Mineralogy 2017, 1, 52-60. (In Russian)

14. Peucat, J.J.; Ruffault, P.; Fritch, E.; Bouhnik-Le-Coz, M.; Simonet, C.; Lasnier, B. Ga/Mg ratio as a new geochemical tool to differentiate magmatic from metamorphic blue sapphires. Lithos 2007, 98, 261-274. [CrossRef] 
15. Sutherland, F.L.; Abduriyim, A. Geographic typing of gem corundum: A test case from Australia. J. Gemmol. 2009, 31, 203-210. [CrossRef]

16. Stone-Sundberg, J.; Thomas, T.; Sun, Z.; Guan, Y.; Cole, Z.; Equall, R.; Emmett, J. Accurate Reporting of Key Trace Elements in Ruby and Sapphire Using Matrix-Matched Standards. Gems Gemol. 2017, 53, 438-451. [CrossRef]

17. Sorokina, E.S.; Koivula, J.I.; Muyal, J.; Karampelas, S. Multiphase fluid inclusions in blue sapphires from the Ilmen Mountains, southern Urals. Gems Gemol. 2016, 52, 209-211.

18. Giuliani, G.; Caumon, G.; Rakotosamizanany, S.; Ohnenstetter, D.; Rakototondrazafy, M. Classification chimique des corindons par analyse factorielle discriminante: Application à la typologie des gisements de rubis et saphirs. Revue Gemmol. 2014, 188, 14-22.

19. Zwaan, J.C.; Buter, E.; Mertz-Kraus, R.; Kane, R.E. The origin of Montana's alluvial sapphires. Gems Gemol. 2015, 51, 370-391.

20. Sorokina, E.S.; Rassomakhin, M.A.; Nikandrov, S.N.; Anosova, M.O.; Kononkova, N.N.; Kuz'mina, T.G.; Romashova, T.V.; Philippova, K.A. Geochemistry of new blue corundum (sapphire) occurrence in Ilmen Mountains, South Urals of Russia: Clues to "metamorphic" sapphire petrogenesis in placer deposits. In Proceedings of the EGU General Assembly 2018, Vienna, Austria, 8-13 April 2018; Volume 20.

21. Azimov, P.Y.; Bushmin, S.A. Solubility of minerals of metamorphic and metasomatic rocks in hydrothermal solutions of varying acidity: Thermodynamic modeling at $400-800{ }^{\circ} \mathrm{C}$ and $1-5 \mathrm{kbar}$. Geochem. Int. 2007, 45, 1210-1234. [CrossRef]

22. Pokrovskii, V.A.; Helgeson, H.C. Thermodynamic properties of aqueous species and the solubility of minerals at high pressures and temperatures: The system $\mathrm{Al}_{2} \mathrm{O}_{3}-\mathrm{H}_{2} \mathrm{O}-\mathrm{NaCI}$. Chem Geol. 1995, 137, 221-242. [CrossRef]

23. Pin, C.; Monchoux, P.; Paquette, J.-L.; Azambre, B.; Wang, R.C.; Martin, R.F. Igneous albitite dikes in orogenic lherzolites, western Pyrénées, France: A possible source for corundum and alkali feldspar xenocrysts in basaltic terranes. II. Geochemical and petrogenetic considerations. Can. Mineral. 2006, 44, 843-856. [CrossRef]

24. Rusin, A.I.; Valizer, P.M.; Krasnobaev, A.A.; Baneva, N.N.; Medvedeva, E.V.; Dubinina, E.V. Origin of the garnet-anortite-clinopyroxene-amphibole rocks from the Ilmenogorskii complex (Southern Urals). Lithosphere 2012, 1, 91-109. (In Russian)

25. Nedosekova, I.L.; Vladykin, N.V.; Pribavkin, S.V.; Bayanova, T.B. The Il'mensky-Vishnevogorsky Miaskite-Carbonatite Complex, the Urals, Russia: Origin, Ore Resource Potential, and Sources. Geol. Ore Depos. 2009, 51, 139-161. [CrossRef]

26. McDonough, W.F.; Sun, S.S. The composition of the Earth. Chem. Geol. 1995, 120, 223-253. [CrossRef]

27. Baneva, N.N.; Medvedeva, E.V.; Rusin, A.I. Geochemical characteristics of ultramafites of the Ilmenogorsky shear zone. Proc. Zavaritsky Inst. Geol. Geochem. (Trudy Instituta Geologii i Geokhimii im. Akademika A.N. Zavaritskogo) 2009, 156, 115-119. (In Russian)

28. Ivanov, K.S. The Main Features of the Geological History (1.6-0.2 Billion Years) and the Structure of the Urals. Unpublished Ph.D. Thesis, Urb RAS, Yekaterinbur, Russia, 1998.

29. Dzikowski, T.J.; Cempirek, J.; Groat, L.A.; Dipple, G.M.; Giuliani, G. Origin of gem corundum in calcite marble: The Revelstoke occurrence in the Canadian Cordillera of British Columbia. Lithos 2014, 198-199, 281-297. [CrossRef]

30. Zhang, Z.-M.; Ding, H.-X.; Dong, X.; Tian, Z.-L.; Mu, H.-C.; Li, M.-M.; Qin, S.-K.; Niu, Z.-X.; Zhang, N. The Eocene corundum-bearing rocks in the Gangdese arc, south Tibet: Implications for tectonic evolution of the Himalayan orogeny. Geosci. Front. 2018, 9, 1337-1354. [CrossRef]

31. Yakymchuk, C.; Szilas, K. Corundum formation by metasomatic reactions in Archean metapelite, SW Greenland: Exploration vectors for ruby deposits within high-grade greenstone belts. Geosci. Front. 2018, 9 , 727-749. [CrossRef]

32. Grapes, R.; Palmer, K. (Ruby-sapphire)-chromian mica-tourmaline rocks from Westland, New Zealand. J Petrol. 1996, 37, 293-315. [CrossRef]

33. Icenhower, J.; London, D. An experimental study of element partitioning among biotite, muscovite, and coexisting peraluminous silicic melt at $200 \mathrm{MPa}\left(\mathrm{H}_{2} \mathrm{O}\right)$. Am. Mineral. 1995, 80, 1229-1251. [CrossRef]

34. Yoder, H.S.; Eugster, H.P. Synthetic and natural muscovites. Geochim. Cosmochim. Acta 1955, 8, $225-280$. [CrossRef] 
35. Storre, B.; Karotke, E. An experimental determination of the upper stability limit of muscovite + quartz in the range 7-20 kb water pressure. Neues Jahrb.Mineral. Monatsh. 1971, 237-240.

36. Merrill, R.B.; Robertson, J.K.; Wyllie, P.J. Melting reactions in the system $\mathrm{NaAlSi}_{3} \mathrm{O}_{8}-\mathrm{KAlSi}_{3} \mathrm{O}_{8}-\mathrm{SiO}_{2}-\mathrm{H}_{2} \mathrm{O}$ to 20 kilobars compared with results for the feldspar-quartz- $\mathrm{H}_{2} \mathrm{O}$ and rock- $\mathrm{H}_{2} \mathrm{O}$ systems. J. Geol. 1970, 78, 558-569. [CrossRef]

37. Althaus, E.; Karotke, E.; Nitsch, K.H.; Winkler, H.G.F. An experimental re-examination of the upper stability limit of muscovite plus quartz. Neues Jahrb. Mineral. Monatsh 1970, 7, 325-336.

38. Hall, A.L. On the marundites and allied corundum-bearing rocks in the Leysdorf district of the Eastern Transvaal. Trans. Geol. Soc. S. Afr. 1923, 24, 43-67.

39. Anhaesseur, C.R. On an Archean marundite occurrence (corundum margarite rock) in the Barberton Mountain Land, Eastern Transvaal. S. Afr. J. Geol. 1978, 81, 211-218.

40. Morrison, E.R. Corundum in Rhodesia; Rhodesia Geological Survey: Salisbury, Zimbabwe, 1972; 24p.

41. Schreyer, W.; Werding, G.; Abraham, K. Corundum-fuchsite rocks in greenstone belts of Southern Africa: Petrology, geochemistry and possible origin. J. Petrol. 1981, 22, 191-231. [CrossRef]

42. Kerrich, R.; Fyfe, W.S.; Barnett, R.L.; Blair, B.B.; Willmore, L.M. Corundum, Cr-muscovite rocks at O’Briens, Zimbabwe: The conjunction of hydrothermal desilicification and LIL-element enrichment-geochemical and isotopic evidence. Contrib. Mineral. Petrol. 1987, 95, 481-498. [CrossRef]

43. Wang, K.K.; Graham, I.T.; Lay, A.; Harris, S.J.; Cohen, D.R.; Voudouris, P.; Belousova, E.; Giuliani, G.; Fallick, A.E.; Greig, A. The Origin of a new Pargasite-Schist Hosted Ruby Deposit from Paranesti, Northern Greece. Can. Mineral. 2017, 55, 535-560. [CrossRef]

44. Guo, J.; O'Reilly, S.Y.; Griffin, W.L. Corundum from basaltic terrains: A mineral inclusion approach to the enigma. Contrib. Mineral. Petrol. 1996, 122, 368-386. [CrossRef]

45. Graham, I.; Sutherland, F.L.; Zaw, K.; Nechaev, V.; Khanchuk, A. Advances in our understanding of the gem corundum deposits of the West Pacific continental margins intraplate basaltic fields. Ore Geol. Rev. 2008, 34, 200-215. [CrossRef]

46. Palke, A.; Wong, J.; Verdel, C.; Ávila, J.N. A common origin for Thai/Cambodian rubies and blue and violet sapphires from Yogo Gulch, Montana, U.S.A.? Am. Mineral. 2018, 103, 469-479. [CrossRef]

47. Wong, J.; Verdel, C.; Allen, C. Trace-element compositions of sapphire and ruby from the eastern Australian gemstone belt. Min. Mag. 2017, 81, 1551-1576. [CrossRef] 